\title{
Regional E-governance Development Index for Developing Nations
}

\author{
RAJAN GUPTA and SUNIL KUMAR MUTTOO, Department of Computer Science, \\ University of Delhi, India \\ SAIBAL KUMAR PAL, Defense Research \& Development Organization, India
}

\begin{abstract}
E-governance has proven to be instrumental in the expansion and evolution of how governments interact with and deliver services to their citizens. The United Nations (UN) E-Governance Development Index (EGDI) is the most widely used metric for assessment of e-governance development; however, this metric is not appropriate for assessment at the regional level, especially for developing nations. Therefore, the authors have studied various factors in the context of developing nations, such as the Online Availability and Performance Index, Telecommunications Index, Human Capital Index, E-governancerelated Infrastructure Index, and E-governance Performance Index, with the aim of analyzing the success and implementation rate of e-governance activities across the different regions of a developing nation like India. The results showed that the UN's EGDI is not suitable for assessment at a regional level and that adding new components to the model helps to achieve better results for around $30 \%$ of the regions under study. The rankings, which were calculated through the new model and compared against other standard indices, obtained good correlations, proving the validity of the new model. India, as a developing nation, was the region selected for the experimental work. Central governments, state governments, investors, stakeholders, and government consultants can obtain benefits through this research.
\end{abstract}

CCS Concepts: • Applied computing $\rightarrow$ E-government;

Additional Key Words and Phrases: E-Governance, E-governance development index, India, United Nations

ACM Reference format:

Rajan Gupta, Sunil Kumar Muttoo, and Saibal Kumar Pal. 2020. Regional E-governance Development Index for Developing Nations. Digit. Gov.: Res. Pract. 1, 3, Article 20 (November 2020), 26 pages.

https://doi.org/10.1145/3386163

\section{INTRODUCTION}

The countries that are successfully climbing up the ladder of e-governance development are those that continuously assess the need for any e-service and transform the regular service into electronic mode. The life cycle of the service is tracked, and its development is assessed from time to time. Assessments help in understanding the work that has been done. They can also help in conducting a comparative analysis among various service areas and different regions that adopt these services. In the literature, there are many studies related to customer-side assessment and willingness to use e-governance services, but there are no major studies that extend modeling

Author's addresses: R. Gupta (corresponding author) and S. K. Muttoo, Department of Computer Science, Faculty of Mathematical Sciences, University of Delhi, North Campus, Delhi-110007, India; emails: \{guptarajan2000, drskmuttoo\}@gmail.com; S. K. Pal, SAG Lab, Metcalfe House, Defense Research \& Development Organisation, Delhi-110054, India; email: skptech@yahoo.com.

Permission to make digital or hard copies of all or part of this work for personal or classroom use is granted without fee provided that copies are not made or distributed for profit or commercial advantage and that copies bear this notice and the full citation on the first page. Copyrights for components of this work owned by others than ACM must be honored. Abstracting with credit is permitted. To copy otherwise, or republish, to post on servers or to redistribute to lists, requires prior specific permission and/or a fee. Request permissions from permissions@acm.org.

() 2020 Association for Computing Machinery.

2639-0175/2020/11-ART20 \$15.00

https://doi.org/10.1145/3386163

Digital Government: Research and Practice, Vol. 1, No. 3, Article 20. Publication date: November 2020. 
over the data and gain insights from it [1]. A willingness and readiness to develop services exist in various countries, but assessment of service development is rare. This may lead to non-standardization of services because of a lack of motivation to work in specific sectors and areas, which can affect the overall e-governance development of the country [2].

The United Nations' (UN) E-governance Report [3] is the standard reporting system used worldwide to assess e-governance development in a country. The report considers the existing infrastructure and quality of services through parameters such as Infrastructure, Human Capital, Telecommunications, and E-participation. Every two years, the UN comes out with rankings on every country to analyze its development on the e-governance front. Like the UN report, every country has its own assessment system. However, most of them are based on the readiness of the country to promote e-governance or on users' willingness to accept electronic services. There are very few assessment criteria that concentrate on development assessment in the respective countries. Some countries, based on the UN's assessment report, have discussed how their respective countries' [4] assessment by the UN can be further evaluated at a regional level. These studies consider data from the UN database only and analyze it further to study the level of development in their respective countries. No customization or generalization of the assessment criteria is carried out, which leaves a question unanswered about the assessment of e-governance development in every country (or a group of countries) on an individual basis based on customized data.

It has been reported that the growth and development of a nation's economy is primarily influenced by its governance approaches and public administration [5]. E-governance is an informative and flourishing aspect of the public sector of developing countries. It has become a prime focus of these countries to achieve citizenoriented and innovative governance [5-7]. Many reports like the e-government survey in the UN Reports of 2012 and 2014 [3, 8], the E-readiness Ranking by The Economist [9], the European Union [10], the E-readiness Index Report [11] of the Government of India, and the report by PricewaterhouseCoopers [7] have shown that many government departments have attempted to measure and evaluate the quality of their service delivery. In India, the E-readiness Index Report [11] was published, which only assessed the readiness of the state to adopt e-government services, but almost 10 years later, when so many services have been developed all around the country, there exists no standard criterion to assess the level of development and analyze how an inclusive egovernance development plan can be achieved. It is important to have assessment programs in place [12, 13]. This article argues for a Regional Development Assessment Index for E-governance in developing nations like India that takes into consideration the factors that are central to the development and success of e-governance service initiatives. This index has been calculated for every region so a comparative analysis can be done for e-governance development in the country. This framework can be generalized for any developing nation having access to data at a granular level. In addition, various data points were searched for different provinces of South Africa, where development can be assessed in a similar manner.

\section{LITERATURE REVIEW}

\subsection{E-governance Model-related Literature}

Various e-governance service assessment models have been developed in the past, but very few have discussed the development assessment of e-governance in specific regions. The development aspect of government systems is not clear in the literature and therefore needs to be highlighted. In a developing economy like India, government projects need to be assessed from a wider perspective, because they are also development projects. The beginning stage of developmental processes is related to the observation of a certain situation, which later becomes the prime object while implementing growth model development theories, which helps in understanding matters related to public policy. Also, e-governance or information and communication technology (ICT) projects are recognizable when seen through the viewpoint of development theory [14-16]. A study conducted by Madon [16] used Sen's notion of capability to assess e-governance projects in India. The study discussed the need to evaluate e-governance projects because these initiatives have long-term developmental effects. A study

Digital Government: Research and Practice, Vol. 1, No. 3, Article 20. Publication date: November 2020. 
by De [15] investigated a few selected e-governance projects to evaluate the system using two approaches: development assessment and project assessment. The study concluded that e-government projects can be declared successful if the objectives are specified only with a supply-side perspective (the project assessment approach), but a wider perspective on the demand side is needed for a development assessment approach.

Development from the governance point of view must be planned and self-sustaining, as outlined by the theory of social development [17]. In addition, this can only be achieved when continuous assessment of the humans and resources involved is performed from an e-governance perspective. As the green revolution in India [18] justified Social Development Theory, the e-governance wave can also lead to social development in the country where every individual becomes self-sustaining and can access government services with ease and transparency. However, without knowing whether growth and development of electronic governance is impacting its citizens from a development point of view, no concrete policy or framework can be prepared for the uplifting of the country in this regard.

Table 1 shows a summary of various models framed in the past by researchers all around the world. The type of work includes models related to functionality assessment of e-governance services, the value provided by various such services, the maturity level of these services, the adoption factors for e-governance services, their development in the past, the evolution of various assessment frameworks, evaluation of e-governance service components such as Web sites, technology, infrastructure, and so on, and the user acceptance level for such services.

\subsection{E-Governance Development Assessment-based Literature}

The research area surrounding the assessment of e-governance development and impact has always been a popular subject among research scholars around the world in multidisciplinary fields such as information technology, management, governance, polity, law, and others. Assessment of the progress of e-governance and of readiness to adopt this practice started around 2000-2001. This was a natural time for researchers to engage in development assessment as e-governance, and more importantly information and communication technology, penetrated the government sector deeply, especially in the western part of the world.

The first of the assessment indices was reported by Welch [53] under the name of the Information Society Index (ISI). This assessment model was developed for 55 countries, principally including the United States and the European and Asian regions, for "The World Paper," managed by the World Times and the International Data Corporation. The digital divide for the various countries was measured through this index, and it was found that the rich get richer and the poor get poorer in terms of the digital divide among the nations. The development index argued that there has been a rise in the usage of information technology by various countries in the public sector, but that the rate of growth is slow.

The next assessment tool was devised by Jung et al. [54] and was called the Internet Connectedness Index (ICI). The major motivation was to find out whether Internet inclusion would enhance the mobility of users in the area of technology and what kind of impact the Internet would have on citizens. The term connectedness was used in the United States rather than the term use/usage. A total of nine items were included in the Internet Connectedness Index. They were related to having a computer at home, the purpose of using the computer for work or education or any other work, number of physical sites to connect to the Internet, the purpose of using the Internet (choosing from pre-defined categories), type of activities pursued over the Internet, time spent on the Internet for carrying out activities, positive or negative impact of the Internet on the user's life, extent of computer dependency for users, and extent of Internet dependency for computer users.

Similarly to ISI and ICI, another model was proposed by Desai et al. [55] and called the Technology Achievement Index (TAI). This model was developed and tested in 72 countries across the world from 1997 to 2000 and addressed technology reach and usage in various countries. This index served as the starting point for the global model developed by the UN in 2001-2002. TAI considered four major parameters: technology creation, diffusion of recent innovations, diffusion of old innovations, and human skills. Technology creation was measured by the number of patents, royalties, and license fees. Diffusion of recent innovation consisted of the number of Internet 
Table 1. Models Proposed in the Literature Review

\begin{tabular}{|c|c|}
\hline$\overline{\text { Model }}$ & Description \\
\hline $\begin{array}{l}\text { Technology Adoption Model } \\
\text { [19] }\end{array}$ & $\begin{array}{l}\text { Assessed the adoption of a technology-based service through its perceived } \\
\text { usefulness and ease of use. }\end{array}$ \\
\hline E-governance Development [4] & $\begin{array}{l}\text { Assessed the UN framework for e-governance development in finer detail } \\
\text { for Arab countries based on its rankings and resources. }\end{array}$ \\
\hline $\begin{array}{l}\text { ICT Readiness for } \\
\text { E-government Organization } \\
{[20]}\end{array}$ & $\begin{array}{l}\text { E-government strategy, user access, e-government program, ICT } \\
\text { architecture, business process and information systems, ICT infrastructure, } \\
\text { and human resources. }\end{array}$ \\
\hline $\begin{array}{l}\text { Technology, Environment } \\
\text { Organization Model [21] }\end{array}$ & $\begin{array}{l}\text { Assessed the adoption of technology-based service through its } \\
\text { technological, organizational, and environmental context. }\end{array}$ \\
\hline E-government Participation [22] & $\begin{array}{l}\text { Assessed the participation level of citizens through development of various } \\
\text { e-government projects. }\end{array}$ \\
\hline $\begin{array}{l}\text { E-governance Readiness } \\
\text { Framework [23] }\end{array}$ & $\begin{array}{l}\text { Assessed the readiness of e-governance through strategy, processes, } \\
\text { technology, and people. }\end{array}$ \\
\hline E-service Evaluation [24] & $\begin{array}{l}\text { Assessed the technical components of an E-service through the client } \\
\text { layer, Web access layer, application layer, and data management layer. }\end{array}$ \\
\hline E-inclusion Gap Model [25] & $\begin{array}{l}\text { Assesses various gaps between provision of a service and its usage among } \\
\text { citizens. }\end{array}$ \\
\hline $\begin{array}{l}\text { E-governance Assessment } \\
\text { Framework [26] }\end{array}$ & $\begin{array}{l}\text { Assessed the impact of key dimensions such as cost, quality, and } \\
\text { governance of various e-governance projects. }\end{array}$ \\
\hline Implementation Factors for & Assessed various factors that led to development of e-governance projects. \\
\hline E-governance [27] & Factors were cost, quality, governance, and comparison of projects. \\
\hline $\begin{array}{l}\text { Factors for Calculating } \\
\text { E-readiness [28] }\end{array}$ & $\begin{array}{l}\text { Assessed various factors required to analyze whether a country is ready to } \\
\text { avail itself of digital services from government. }\end{array}$ \\
\hline $\begin{array}{l}\text { E-governance Adoption Model } \\
\text { [29] }\end{array}$ & $\begin{array}{l}\text { Assessed the factors that led to adoption of e-government services in a } \\
\text { country by citizens so, accordingly, these can be highlighted during } \\
\text { development. }\end{array}$ \\
\hline Web Site Assessment [30] & $\begin{array}{l}\text { Assessed the Web sites of municipal corporations in the United States } \\
\text { under state governments. }\end{array}$ \\
\hline Assessment of an Online & Assessed various characteristics such as users, suppliers, content \\
\hline Government Service [31] & dimension, and program dimension for an online government service. \\
\hline E-government Assessment & Prepared a framework to assess e-government services using the maturity \\
\hline EGOV4SD [33] & Assessed literature on various e-governance assessment frameworks. \\
\hline $\begin{array}{l}\text { E-governance Implementation } \\
\text { Factors [13] }\end{array}$ & $\begin{array}{l}\text { Assessed the various factors that are critical and important for successful } \\
\text { implementation of e-governance. }\end{array}$ \\
\hline Quality Assessment [34] & $\begin{array}{l}\text { Assessed the quality of e-services through process performance, technical } \\
\text { performance, site quality, and customer satisfaction. }\end{array}$ \\
\hline $\begin{array}{l}6 \text { Essential Factors for } \\
\text { Government Services [35] }\end{array}$ & $\begin{array}{l}\text { Assessed the different kinds of value that a government service project in } \\
\text { electronic form provides to its environment. }\end{array}$ \\
\hline $\begin{array}{l}\text { E-government Maturity Model } \\
\text { [36] }\end{array}$ & $\begin{array}{l}\text { Assessed the maturity of e-governance services through information } \\
\text { criteria, IT resources, and leverage domains. }\end{array}$ \\
\hline
\end{tabular}


Table 1. Continued

\begin{tabular}{|c|c|}
\hline Model & Description \\
\hline $\begin{array}{l}\text { E-governance Success Factors } \\
{[37]}\end{array}$ & $\begin{array}{l}\text { Assessed the various factors that led to success of e-governance in various } \\
\text { states of India. }\end{array}$ \\
\hline E-electioneering Analysis [38] & $\begin{array}{l}\text { Assessed a specific e-governance service for its development and } \\
\text { functioning. }\end{array}$ \\
\hline E-services Evaluation [39] & $\begin{array}{l}\text { Assessed development of e-governance by evaluating e-services on } \\
\text { environment maturity, back office, front office, and impact on citizens. }\end{array}$ \\
\hline $\begin{array}{l}\text { SALT Framework \& Quality } \\
\text { Model [40] }\end{array}$ & $\begin{array}{l}\text { Assessed the online technicalities and architecture of online service portals } \\
\text { of government. }\end{array}$ \\
\hline $\begin{array}{l}\text { E-records Management } \\
\text { Assessment Tool [41] }\end{array}$ & $\begin{array}{l}\text { Assessed a specific e-governance service for its infrastructure, } \\
\text { development, and capability for delivery. }\end{array}$ \\
\hline Application Assessment [42] & Assessed various applications of e-government services. \\
\hline $\begin{array}{l}\text { COBRAS, VMM, D\&M, } \\
\text { SERVQUAL Models [43] }\end{array}$ & $\begin{array}{l}\text { Assessed various aspects of an e-service for good operation and the value } \\
\text { that each provides. }\end{array}$ \\
\hline $\begin{array}{l}\text { Evolution of E-readiness } \\
\text { Assessment [44] }\end{array}$ & $\begin{array}{l}\text { Assessed the development and evolution of various frameworks for } \\
\text { e-readiness assessment around the world. }\end{array}$ \\
\hline E-governance Adoption [45] & Assessment of various challenges needed for e-governance adoption. \\
\hline $\begin{array}{l}\text { E-governance Readiness } \\
\text { Challenges [46] }\end{array}$ & $\begin{array}{l}\text { Assessed various challenges with respect to readiness for e-governance } \\
\text { projects. }\end{array}$ \\
\hline E-governance Adoption [1] & Assessment of adoption for e-governance services. \\
\hline E-government Maturity [47] & $\begin{array}{l}\text { Considered ICT infrastructure, human capital, and quality of governance } \\
\text { to assess maturity. }\end{array}$ \\
\hline $\begin{array}{l}\text { E-governance for Improved } \\
\text { Public Sector Delivery [48] }\end{array}$ & $\begin{array}{l}\text { Assessed the impact of e-governance services for improved public service } \\
\text { delivery in various nations. }\end{array}$ \\
\hline Implementation Factors for & Assessed various factors that led to development of e-governance projects. \\
\hline E-governance [49] & $\begin{array}{l}\text { The factors were maturity, challenges, opportunities, and success of a } \\
\text { project. }\end{array}$ \\
\hline $\begin{array}{l}\text { E-governance Web Site } \\
\text { Assessment [50] }\end{array}$ & Assessment of evolution of various e-governance Web sites. \\
\hline $\begin{array}{l}\text { E-government Service } \\
\text { Requirements [51] }\end{array}$ & $\begin{array}{l}\text { Assessed the technology and usage-based information and infrastructure } \\
\text { required to access various e-government services. }\end{array}$ \\
\hline $\begin{array}{l}\text { E-government Service } \\
\text { Framework (Value) [52] }\end{array}$ & $\begin{array}{l}\text { Assessed the different values that any e-government service will provide to } \\
\text { various stakeholders and the environment in which it operates. }\end{array}$ \\
\hline
\end{tabular}

hosts, whereas that for old innovations consisted of telephone and electricity users. Human skills were covered by schooling pattern and enrollment ratio. UN - DPEPA [56] came up with a global E-Governance Index (EGI) for the 190 member nations of the UN to assess the development and readiness for each country on the aspect of e-governance.

Apart from the global index developed by the UN, some researchers kept on developing indices to assess e-governance and to measure ICT penetration in various nations. One such measure developed in the literature was the Digital Divide Index (DDIX) by Selhofer \& Hüsing [57]. Based on diffusion theory, the DDIX was formulated for countries that were members of the European Union. The index was tested on a dataset for 19972000 and showed that socioeconomic factors played an important role in impacting the digital divide among citizens in various countries. Hüsing \& Selhofer [58] further worked on the DDIX and collected data for 2002 as 
well as 1997 and 2000, while keeping the indicators the same as in the previous study. It was found that overall the DDIX for the 15 nations remained almost the same.

Apart from the DDI, one more index [59] was developed on the basis of digital access by the International Telecommunication Union (ITU) in 2003 and was called the Digital Access Index (DAI). The argument behind the development of such an index was that all the earlier indices were mainly constructed for developed countries and had flaws in their development methodologies. ICT access was not targeted specifically, and parameters were too numerous in the earlier indices.

Apart from DAI, another index proposed by ITU [60] was the Digital Opportunity Index (DOI). This was different from the DAI in the sense that the DOI measured the digital opportunity in various countries to access the various resources present online and to use them for good governance. It measured three components (opportunity, infrastructure, and utilization) and presented rankings for 180 nations. The results were similar to those obtained for the DAI. The DOI added an analysis of the potential that each country possessed for increasing the access to ICT among its residents.

Another global index developed by Dutta et al. [61] was the Networked Readiness Index (NRI), proposed in 2001 through the Global Information Technology Report. The NRI was composed of three components: environment, readiness, and usage. The various sub-indices were related to the market, political, and infrastructure environment; individual, business, and government readiness for networks and ICT; and usage level of ICT at the individual, business, and government levels. Dutta \& Mia [62] presented the NRI values for 133 countries in 2009-2010 and found that the top countries were Sweden, Singapore, Denmark, Switzerland, the United States, and Finland. Baller et al. [63] further worked on the NRI and added a sub-index called the Impact on Economic and Social Aspects for each country. Fifty-three indicators were added to the NRI from various international sources such as the ITU, World Bank, UNESCO, and the World Economic Forum. A total of 139 nations were included in the NRI rankings, which accounted for almost 98\% of the GDP of the world.

Similarly to global indices like the EGI and NRI, there was a university research project that was developed into an international ranking method for countries on the e-government front. Toshio [64] developed e-government rankings at Waseda University in Japan from 2005 to 2009. The ranking survey was popularly known as the Waseda rankings for e-government. It covered various components such as preparedness for the Internet and related uses, existence of user-friendly interfaces for various e-governance applications, optimization of management, the look and feel of the homepage of various applications and the country's respective government home pages, the appointment of a Chief Information Officer in various countries for every application and department, and e-government promotion through various channels. Out of a total of 34 countries evaluated in the survey rankings, the countries that did well on EGI and NRI were also the ones that were high on the Waseda rankings. The top countries for the rankings along the various years (2005, 2006, 2007, 2008, and 2009) were the United States, Singapore, Canada, Japan, the United Kingdom, Korea, and Finland. Obi and Iwasaki [65] continued with the rankings from Waseda University and found that similar countries were on top for 2009 to 2015.

Apart for preparation for ICT usage, some researchers also worked on the cybersecurity aspect of using ICT in the public sector, which was also included as a variable in the Waseda rankings. Hathaway [66] proposed and developed a basic-level Cyber Readiness Index (CRI) to study whether countries are prepared to deal with cyber security attacks. A total of 35 countries were assessed for their maturity towards cyber-attacks. Basic elements checked for each country included whether the country had a computer emergency response team and whether the country had shown signs of installing protection against any cyber-crime. Whether the country was investing in cyber infrastructure was also assessed. According to the initial results, countries such as Australia, the United States, the United Kingdom, Canada, and the Netherlands were found to be more cyber-ready than other countries around the world.

Table 2 shows a summary of the various indices existing in the world. The E-Governance Development Index (EGDI) developed by the UN [67] remains the most effective and widely accepted assessment index in the world. The UN came out with world rankings of various countries for 2001, 2003, 2004, 2005, 2008, 2010, 2012, 2014,

Digital Government: Research and Practice, Vol. 1, No. 3, Article 20. Publication date: November 2020. 
Table 2. Summary of Assessment Indices in the Area of E-governance

\begin{tabular}{|c|c|c|c|}
\hline Index & Components & Level of Application & Type of Data \\
\hline $\begin{array}{l}\text { Information Society Index } \\
\text { (ISI) }-2000\end{array}$ & $\begin{array}{l}4 \text { - Computer, Internet, } \\
\text { Information, and Social } \\
\text { infrastructure }\end{array}$ & $\begin{array}{l}\text { Country level } \\
\text { (55 countries) }\end{array}$ & Secondary data \\
\hline $\begin{array}{l}\text { Internet Connectedness } \\
\text { Index (ICI) - } 2000\end{array}$ & $\begin{array}{l}9 \text { statements on general } \\
\text { connectedness components }\end{array}$ & $\begin{array}{l}\text { Regional level } \\
\text { (1 state with } 7 \text { regions) }\end{array}$ & Scale-based primary data \\
\hline $\begin{array}{l}\text { Technology Achievement } \\
\text { Index (TAI) - 1997-2000 }\end{array}$ & $\begin{array}{l}4 \text { - Technology creation, Diffusion } \\
\text { of recent innovations, Diffusion of } \\
\text { old innovations, Human skills }\end{array}$ & $\begin{array}{l}\text { Country level } \\
\text { ( } 72 \text { countries) }\end{array}$ & Secondary data \\
\hline $\begin{array}{l}\text { E-Governance Index } \\
\text { (EGI) - } 2001\end{array}$ & $\begin{array}{l}3 \text { - Human capital, Online web } \\
\text { presence, Telecommunication } \\
\text { infrastructure }\end{array}$ & $\begin{array}{l}\text { Country level } \\
\text { (190 nations) }\end{array}$ & $\begin{array}{l}\text { Primary and secondary } \\
\text { data }\end{array}$ \\
\hline $\begin{array}{l}\text { Digital Divide Index } \\
\text { (DDIX) - 1997-2000 }\end{array}$ & $\begin{array}{l}\text { 4-5 Statements for measuring the } \\
\text { digital divide across different } \\
\text { demographics }\end{array}$ & $\begin{array}{l}\text { Country level } \\
\text { (15 countries from the } \\
\text { European Union) }\end{array}$ & $\begin{array}{l}\text { Primary and secondary } \\
\text { data }\end{array}$ \\
\hline $\begin{array}{l}\text { Digital Access Index } \\
\text { (DAI) - } 2003\end{array}$ & $\begin{array}{l}5 \text { - Infrastructure, Affordability, } \\
\text { Knowledge, Quality, and Usage }\end{array}$ & $\begin{array}{l}\text { Country level } \\
\text { (178 countries) }\end{array}$ & Secondary data \\
\hline $\begin{array}{l}\text { Digital Opportunity Index } \\
\text { (DOI) - } 2005\end{array}$ & $\begin{array}{l}3 \text { - Opportunity, Infrastructure, } \\
\text { and Utilization }\end{array}$ & $\begin{array}{l}\text { Country level } \\
\text { (180 countries) }\end{array}$ & Secondary data \\
\hline $\begin{array}{l}\text { Network Readiness Index } \\
\text { (NRI) - 2001-16 }\end{array}$ & $\begin{array}{l}3 \text { - Environment, Readiness, } \\
\text { and Usage }\end{array}$ & $\begin{array}{l}\text { Country level } \\
\text { (102 countries) }\end{array}$ & Secondary data \\
\hline $\begin{array}{l}\text { Cyber Readiness Index } \\
\text { (CRI) - } 2013\end{array}$ & Basic cyber readiness components & $\begin{array}{l}\text { Country level } \\
\text { (35 countries) }\end{array}$ & Secondary data \\
\hline $\begin{array}{l}\text { Waseda Rankings - } \\
\text { 2005-09 }\end{array}$ & $\begin{array}{l}6 \text { - Internet users, User-friendly } \\
\text { interface, Management } \\
\text { optimization, UI of Website, CIO, } \\
\text { Promotion }\end{array}$ & $\begin{array}{l}\text { Country level } \\
\text { (34 countries) }\end{array}$ & $\begin{array}{l}\text { Secondary and primary } \\
\text { data }\end{array}$ \\
\hline $\begin{array}{l}\text { E-Governance } \\
\text { Development Index } \\
\text { (EGDI) - 2003-18 }\end{array}$ & $\begin{array}{l}3 \text { - Human capital, Online Web } \\
\text { presence, Telecommunication } \\
\text { infrastructure }\end{array}$ & $\begin{array}{l}\text { Country level } \\
\text { (192 countries) }\end{array}$ & Secondary data \\
\hline
\end{tabular}

2016, and 2018. This is a benchmark index used by various nations for assessing their development. Apart from the EGDI, the Waseda rankings and the NRI are frequently published. EGDI started as EGI in 2001 with three components and stuck with those components until 2018; however, an additional Electronic Participation index was added in subsequent years, which was evaluated independently. All these three indices (Waseda, EGDI, and NRI) have few features related to the Internet, although references to telecommunications are common, and some components are specific to the index developed. Even the rankings of the countries on these indices showed similar results, thereby validating the development of each new index independently.

However, over time, many researchers have criticized the workings and development of indices like EGDI. Whitmore [68] conducted a statistical analysis on the data used for EGDI development and testing by the UN. It was found that factor analysis, conducted on the UN dataset, yielded a somewhat different set of components for the index. Moreover, the weights given to each component of the index were not appropriate. Similarly, Ayanso et al. [69] claimed that the current EGDI can be developed in three or four different ways with the help of principal component analysis. The authors constructed four different variants of the EGDI and compared the results with the base index values. Empirical evidence helped the authors to establish the efficacy of their index. However, the various versions of the index did not alter the rankings of the countries too much, but provided a different viewpoint on the development of any global index. 
Rorissa et al. [70] even commented that the current EGDI is a complex index with shortcomings, like not differentiating between a static Web site and a fully integrated dynamic Web site in the score calculation. In addition, the authors suggested that weights were not assigned on the basis of the development of e-governance in a country. Rather, static weights were allocated to the components for different countries. Potnis [71] also analyzed EGDI development and testing with a theoretical framework and came up with suggestions for improving the index. The author suggested that the index should consider interrelationships between people, process, and place through knowledge management and knowledge transfers. Along with this, more emphasis should be given to including electronic participation of citizens in the EGDI, and the assessment of e-governance projects with their returns on investment should be made a part of the evaluation process. Project management and portfolio management should be included in the assessment of e-governance development.

Many indices have been developed in the past at the country level, but they are not assessing nations at the regional level. Moreover, existing indices have their own methodology and shortcomings, which can be overcome by proposing a modified index at regional level for countries ranked in the middle or on the low side of the various global indices.

\section{RESEARCH PROBLEM}

Various studies have been conducted to assess e-governance development, and various components have also been suggested for the assessment process. However, there exist multiple gaps in the literature, which could have an impact on the development of e-governance around the world. The gaps are discussed below.

- Similar index for assessment of developed, developing, and under-developed nations.

All the major global indices are focused on using similar scales for measuring the growth and development of e-governance in developed, developing, and under-developed nations. Because of this, every year the rankings of the countries on the various indices show minimal change. Rich nations are getting richer, while the poor nations are getting poorer, as confirmed by these indices. Even if the developing and under-developed nations have progressed on the development of e-governance, their progress is not being assessed through these indices, because most of the indices use normalized values. In this way, the comparison continues to take place among the developed nations, which are already enjoying the luxury of high e-governance development, whereas the improvements in developing and under-developed nations remain marginal or unnoticed. This gap is also supported by Development Theory [72] and Organization Theory [73], which means that developing or under-developed nations may not be able to track their progress and work towards improvement purely based on their rankings on these global indices.

- Indices are missing to assess e-governance at regional level within a nation.

One of the other major issues with the literature is that there are no assessment models, frameworks, or indices given to assess the development of e-governance within a particular nation. Applying country-level models at the regional level within a nation may not produce the same results. In addition, all the components of a countrylevel index may not be applicable to the smaller regions of any nation. For example, patent filing and technology creation may occur only in a specific region of the country and not in other regions. Similarly, infrastructure development may vary significantly from one region to another.

- No mention of the improvement in value for the components of any index.

Once separate indexing has been performed for developing or under-developed nations and the regional level of development of these nations in e-governance has also been assessed, another gap becomes apparent: There are very few studies on improving the various components of any index for nations, whether at country or regional level. Merely pointing out the weakness of any region based on a low value is not sufficient for

Digital Government: Research and Practice, Vol. 1, No. 3, Article 20. Publication date: November 2020. 
improving e-governance in any nation. Rather, improvement strategies must be suggested for the nations to work towards better rankings of their regions and thus overall development of the nation at the global level. No studies to date can exhaustively comment upon the improvement of various components of a development assessment index at any level. This is in line with sustainability development theory [74], which says that weak regions need to improve to ensure economic, financial, and social sustainability.

- Non-inclusion of evolving technological changes in the index.

According to the New Public Management Theory [75], with changing technologies and an evolving world, the assessment of e-governance should also continuously evolve and consider aspects that are relevant to the particular region and time. Some studies have been found where new components were added to the assessment index; however, more concrete empirical evidence is required to support their inclusion.

- Overdependence of indices on a few components.

More global indices such as EGDI and NRI have been found to be over-reliant on a few components for index development. There is a need to involve a greater number of components that are independent of each other and can help in measuring e-governance development in any nation.

Although many studies and analyses have been done on the meaning, definition, assessment, and predicted implications of e-governance, very few have discussed the development assessment and success of e-governance initiatives across the globe. The UN E-Governance Survey report [3, 8] is the primary and most widely studied report that has quantified the process of e-governance development in the form of an EGDI for nations worldwide. However, no such study seems to have analyzed the development of e-governance service initiatives in any country's regions, states or union territories, particularly in a large developing nation like India. The studies that have been done on matters related to e-governance in India seem to be concentrated on analyzing the services mostly on a qualitative scale, measuring the suitability and performance of online platforms for the services available, and discussing the most popular e-governance service initiatives in India. Only the E-Readiness Assessment Index Report of the Government of India [11] has taken a quantitative scale of measurement into consideration, but the study elaborated on the readiness of the Indian states to implement electronic services. Therefore, an in-depth quantitative analysis of the growth and development of Indian e-governance service initiatives is needed. In addition, a comparative analysis between the states and union territories is required to point out states that have done well and poorly in various aspects of e-governance development. Moreover, researchers like Potnis \& Pardo [44] have also strongly pointed out the lack of standardization in e-governance development assessment, indicating an immediate need to develop a standard measure to assess e-governance development status in any country.

The basic premise for an assessment index at regional level is based on the agglomerative approach towards overall e-governance improvement at the country level. A country may have some regions that are contributing to its overall success in e-governance, but other regions may be struggling to contribute. This can be a misleading outcome for many countries that are doing well on the e-governance front, and even more so in the case of developing nations. Every nation must be able to identify its strong and weak regions and must work continuously to improve their performance. Any improvement achieved at the regional level will ultimately influence development at the country level.

In addition, the concept of a regional index is not new for developing nations. Many such indices exist for the various regions and states in nations like India. For example, India has a Human Development Index, India Innovation Index, Health Index, State Hunger Index, Child Development Index, State Development Potential Index, Gender-related Development Index, Environmental Sustainability Index, and Financial Inclusion Index. Therefore, regional indices already exist and provide another strong reason to develop a similar index for e-governance development assessment at regional level, as proposed in the current article.

Digital Government: Research and Practice, Vol. 1, No. 3, Article 20. Publication date: November 2020. 


\section{PROPOSED TECHNIQUE}

\subsection{Existing Model}

The existing model for the (EGDI) was developed by the UN $[3,8]$ at country level and is given as Equation (1):

$$
\mathrm{UN}-\mathrm{EGDI}=\sum_{i=1}^{3} \alpha_{i} * X_{i},
$$

where $X_{i}$ are the components determining the index and $\alpha_{i}$ are the weights' associated with component $X_{i}$. The various components identified are $X_{1}=$ Telecommunication Index, $X_{2}=$ Human Capital Index, and $X_{3}=$ Online Availability and Presence Index.

The above model cannot be considered for regional assessment in developing nations. In the first place, the model is not implemented for assessment at regional level. The model has country-level features that are not suitable for regional assessment, which is why the model has not been implemented at regional level. Second, no outcome-based components have been included in the model, which are related to e-governance performance to reward a country/region for its good usage of e-governance. Certain regions, even after performing well on the e-governance front, are still ranked very low due to the exclusion of any performance measure from the existing model. Third, no e-governance-specific infrastructure measure has been included in the model to consider a country's better preparedness for e-government infrastructure. Fourth, the index is sensitive to changes in the values of the three components, meaning that a slight change in the value of one component can lead to a drastic change in the rankings. The overdependence of this index on a limited number of components needs to be reduced. Last, no qualitative measure has been included in the assessment to support the quantitative analysis. Therefore, the existing model needs to be redefined with respect to customization at the regional level, especially for developing nations.

\subsection{Proposed Model}

The proposed framework includes the development of an assessment index that focuses on scoring and ranking the various aspects of e-governance development in any region. These aspects have been adopted from the UN's EGDI model and earlier research studies that have considered a few important aspects related to egovernance. The prominent components associated with e-governance and its development are the infrastructure for e-governance setup, the human capital involved, the telecommunication facilities in place, online availability and service quality, electronic participation of citizens, and security related to the various services.

Infrastructure plays a key role in development assessment of e-governance projects [76]. Unless infrastructure is provided, development work is not possible, and services cannot reach out to every corner of the region. Broadlevel infrastructure includes setting up optical fiber-based Internet and establishing of data centers in every state and region. However, at the service level, the number of running services and common service centers at various places to make these online services accessible to the people plays an important part. Therefore, the number of these infrastructural units in any region (operational and planned/upcoming) would be vital in assessing the infrastructural development of that region [76].

Although the Infrastructure component should also consider the telecommunication service aspect because Internet accessibility is crucial for using online services [77], the e-governance-specific infrastructure will be set up more on the government side, whereas telecommunications can be set up by private players also, although it may or may not be accessible by citizens in a region. Because access to a mobile phone is an individual's choice, however, the availability of a mobile tower in a region should be either the responsibility of government or a private player. Considering all this, telecommunication access would still be beneficial for development assessment, because large numbers of people with access would impact whether e-governance services in a region would achieve their potential response. Therefore, key parameters [78] such as the number of broadband connections,

Digital Government: Research and Practice, Vol. 1, No. 3, Article 20. Publication date: November 2020. 
fixed-line connections, mobile connections, and so forth, can be used to formulate the Telecommunications assessment index.

Human Capital is also an essential part of e-governance projects, because it is the demand-side determinant of Internet usage [79]. Because e-governance aims to make people work on their own to avail themselves of services, their basic capability will play an important part in the development assessment. An illiterate person will find it hard to access the service, with basic education therefore becoming a key requirement for e-governance service access. The literacy rate will determine the current capability of a region's population to make use of e-government services, whereas gross enrollment rate and school drop-out rates will determine the future capability of the population to handle these services. The success of e-governance services on the current basis heavily depends on the literacy rate, because the self-sufficiency objective of such projects would not be served by introducing helper agents. Moreover, in combination with common service centers or rural kiosks/tele-centers, government representatives could provide support to people without adequate educational backgrounds and in regions having less individual telecommunication access.

Online Availability and Presence must be addressed in any development assessment. A good e-governance service that does not attract much response may be attributed to poor online presence. Key parameters of Web development should therefore be quantified and must be included in the assessment parameter. Many Web site assessment frameworks are available in the literature [80-82], through which an e-governance service's online presence can be assessed and rated on various dimensions.

Development of e-governance services also heavily depends upon electronic participation in those services. Even when the appropriate infrastructure, adequate telecommunication facilities, good online presence, and enhanced human capabilities in terms of literacy have been provided, lack of willingness to access the service through online mode would be a major setback for the government. For this reason, electronic participation must be tracked over various services in different regions and states. An electronic transaction aggregation and analysis layer is already recording such numbers across various departments, states, and service areas (www. etaal.gov.in) in developing nations like India. These numbers can be normalized for the various regions, and conclusions can be drawn about the electronic participation of citizens in the various services.

According to various research studies [83, 84], privacy and security of transactions through government Web sites has also been found to be a worrisome factor for citizens. Therefore, enhanced security features have been implemented to give more comfort to users. However, in the very beginning, basic security aspects must be considered for e-governance development, and existing services must be assessed for these aspects. Hence, security should also be one of the major aspects of development assessment. It can be combined with online Web presence assessment as well. In this way, a function can be derived, as shown in Equation (2), for the assessment index (AI), which can be a combination of the various components discussed above:

$$
\mathrm{AI}=\mathrm{f}(\mathrm{I}, \mathrm{T}, \mathrm{H}, \mathrm{O}, \mathrm{E}, \mathrm{S}),
$$

where I refers to the Infrastructure component, $\mathrm{T}$ refers to the Telecommunication component, $\mathrm{H}$ refers to the Human Capital component, O refers to Online availability of service and its quality component, E refers to the Electronic participation component, and S refers to the Security component for the e-governance service.

All these components should be calculated with respect to the population size of the region or state and must cater to the needs of everyone equally. The geographical area of a region or state should not by itself be the criterion for resource allocation, e-governance service acceptance, and success. The function used by the UN includes a weighted average of different components to calculate the final score; however, the weights may vary for these components according to different regional and national conditions in different countries. In developing nations, equal weighting of all components should work well due to the diversity and availability of all these components.

The suggested solution can overcome various shortcomings of the EGDI model developed by the UN. First, the assessment index (AI) takes region-specific data into consideration rather than overall country-level data.

Digital Government: Research and Practice, Vol. 1, No. 3, Article 20. Publication date: November 2020. 
Second, e-governance performance indicators are incorporated as outcome variables. Third, an e-governancerelated Infrastructure indicator is incorporated for better development assessment. Fourth, a greater number of e-governance-related parameters decreases sensitivity. Last, online performance and security as qualitative aspects have been included in the assessment. Therefore, a Regional E-Governance Development Index (REGDI) can be formally defined as shown in Equation (3):

$$
\text { REGDI }=\sum_{i=1}^{5} \alpha_{i} * X_{i},
$$

where $X_{i}$ are the components determining the index, and $\alpha_{i}$ are the weights ${ }^{*}$ associated with the component $X_{i}$ 's. The various components identified for the model are $X_{1}=$ Telecommunication Infrastructure Index (TII), $X_{2}=$ Human Capital Index (HCI), $X_{3}=$ Online Availability \& Performance Index (OAPI), $X_{4}=$ Electronic Governance Performance Index (EGPI), and $X_{5}=$ E-Governance-related Infrastructure Index (EGII), which are normalized between 0 and $1,0 \leq$ REGDI, $X_{1}, X_{2}, X_{3}, X_{4}, X_{5} \leq 1$. The security aspect has not currently been considered in the model but can be included once the security assessment scores of all the organizations are available.

\subsection{Research Flow}

Five major steps are involved in index generation for e-governance development assessment at regional level. First, the data are extracted from different primary and secondary sources. The primary information has been collected by assessing various Web sites of e-governance projects at regional level. Secondary data are collected from various official sources for different variables from different ministry and state portals. Second, data transformations are applied to facilitate the calculations. Two types of transformations are used for this purpose: log transformation and population transformation (per 100-person conversion of a metric). Performance indicators of the index must be on an equal scale to have high accuracy. This is achieved by applying log transformation. Tukey [85] noted that transforming amounts and counts to a log scale often helps to "normalize" the measures. Log transformation is used on the performance indicators of the EGPI and the EGII. Population transformation is applied so regional impact can be minimized with respect to population. Therefore, all the key metrics were considered per 100 population, enabling consistent evaluation among all the parameters.

The transformed values of the performance indicators were used in standardization, which is the third step. This step consists of scaling the transformed performance indicators to have a mean value of zero and a standard deviation of one. Standardizing the transformed measures keeps the values of a region or a performance indicator on the same scale. For example, the values of wireless subscriber base per 100 people show high variation. Hence, to have values on the same scale, standardization was performed. It also reduces the effect of outliers and provides a normally distributed curve. A standard z-score was calculated for each performance indicator. The fourth step was to assign weights to each component and its individual parameters. Generally, the parameters of the United Nations EGDI model were used to assign the weights. Once the weights had been assigned to each component, the index was normalized. Normality ensures good separation in the tails of the distribution. Each index was scaled to have a mean of zero and a variance of one. Normalized values for every region for each index were then calculated.

\section{IMPLEMENTATION}

\subsection{Components and Variables}

The various components and associated variables are summarized in Table 3, followed by the formal definitions of each.

Telecommunication Infrastructure Index. The TII takes into consideration the ICT infrastructure capacity of a telecom region. The performance indicators of TII are listed below.

Digital Government: Research and Practice, Vol. 1, No. 3, Article 20. Publication date: November 2020. 
Table 3. Components and Variables for the Proposed Model

\begin{tabular}{|c|c|c|c|c|}
\hline Component & Variables & Component Weights & Source & Formula \\
\hline $\begin{array}{l}\text { Telecommunication } \\
\text { Infrastructure Index } \\
\text { (TII) }\end{array}$ & $\begin{array}{l}\text { Mobile, fixed line, } \\
\text { wired and wireless } \\
\text { broadband, Internet }\end{array}$ & $1 / 5,1 / 5,1 / 5,1 / 5,1 / 5$ & TRAI & $\begin{array}{c}\text { TII }= \\
\frac{T I I_{\text {Region }}-T I I_{\text {Lowest }}}{\text { TII }} \\
\text { Highest }-T I I_{\text {Lowest }}\end{array}$ \\
\hline $\begin{array}{l}\text { Human Capital Index } \\
\text { (HCI) }\end{array}$ & $\begin{array}{l}\text { Gross enrollment rate, } \\
\text { adult literacy, average } \\
\text { years of schooling }\end{array}$ & $4 / 9,3 / 9,2 / 9$ & $\begin{array}{l}\text { data.gov.in } \\
\text { INDIASTAT } \\
\text { niti.gov.in } \\
\end{array}$ & $\begin{array}{c}H C I= \\
\frac{H C I_{\text {Region }}-H C I_{\text {Lowest }}}{H C I_{\text {Highest }}-H C I_{\text {Lowest }}}\end{array}$ \\
\hline $\begin{array}{l}\text { Online Availability \& } \\
\text { Presence Index } \\
\text { (OAPI) }\end{array}$ & $\begin{array}{l}\text { Functionality, design, } \\
\text { security, and user } \\
\text { friendliness }\end{array}$ & $\begin{array}{l}1=\text { Service Complete, } \\
0.5=\text { Service } \\
\text { Incomplete, } \\
0=\text { Service } \\
\text { Unavailable }\end{array}$ & $\begin{array}{l}\text { Service Web site } \\
\text { for every state }\end{array}$ & $\begin{array}{c}O A P I= \\
\frac{O A P I_{\text {Region }}-O A P I_{\text {Lowest }}}{\text { OAPI Highest }}-O A P I_{\text {Lowest }}\end{array}$ \\
\hline $\begin{array}{l}\text { E-Governance- } \\
\text { Related Infrastructure } \\
\text { Index (EGII) }\end{array}$ & $\begin{array}{l}\text { Operational CSCs, } \\
\text { number of e-services, } \\
\text { number of state data } \\
\text { centers }\end{array}$ & $2 / 5,2 / 5,1 / 5$ & csc.gov.in & $\begin{array}{c}E G I I= \\
\frac{E G I I_{\text {Region }}-E \bar{G} I I_{\text {Lowest }}}{E G I I_{\text {Highest }}-E G I I_{\text {Lowest }}}\end{array}$ \\
\hline $\begin{array}{l}\text { E-Governance } \\
\text { Performance Index } \\
\text { (EGPI) }\end{array}$ & $\begin{array}{l}\text { E-transactions per } \\
\text { CSC and per service }\end{array}$ & $1 / 2,1 / 2$ & E-TAAL & $\begin{array}{c}E G P I= \\
\frac{E G P I_{\text {Region }}-E G P I_{\text {Lowest }}}{E G P I_{\text {Highest }}-E G P I_{\text {Lowest }}}\end{array}$ \\
\hline
\end{tabular}

- Wireless tele-density measures the number of mobile-cellular subscriptions per 100 population.

- Wireline tele-density measures the number of fixed-line telephone subscriptions per 100 population.

- Wireless subscriber base measures the number of wireless broadband subscriptions per 100 population.

- Wireline subscriber base measures the number of fixed-line (wired) broadband subscriptions per 100 population.

- Internet subscribers denoted the total number of Internet subscribers per 100 population.

The final equation for the TII is shown as Equation (4):

$$
\begin{aligned}
\text { TII }= & ((1 / 5) * \text { wireless subscriber base per } 100+(1 / 5) * \text { wireline subscriber base per } 100 \\
& +(1 / 5) * \text { mobile subscriber per } 100+(1 / 5) * \text { basic phone subscriber per } 100 \\
& +(1 / 5) * \text { internet subscribers per } 100)_{z-\text { score }}
\end{aligned}
$$

Human Capital Index. The HCI takes a lifelong approach to human capital, evaluating literacy, gross enrollment, expected years of schooling, and mean years of schooling for both rural and urban areas across different regions. The definitions of the four indicators are given below.

- Literacy is measured as the percentage of people who can read and write a short simple statement in everyday language along with understanding.

- Gross enrollment ratio is measured by combining the primary, secondary, and tertiary gross enrollment ratios of the total number of students enrolled at the primary, secondary, and tertiary level, regardless of age, to the population of school age for that level.

- Expected years of schooling represent the total years of schooling that a child of a certain age can expect to receive in the future, with the assumption that the probability of his or her being in school at any age equals the current enrollment ratio for that age.

- Mean years of schooling (MYS) represents the average number of years of education that have been completed by a country's adult population ( 25 years or older), excluding the years spent on repeating grades.

Digital Government: Research and Practice, Vol. 1, No. 3, Article 20. Publication date: November 2020. 
The Human Capital Index can be formulated using Equation (5). The expected years of schooling data were not available for all regions; therefore, its weight of 2/9 has been given to Gross Enrollment right now as in the United Nations' report in 2012, and the 2/9 weighting of mean years of schooling has been split into rural and urban regions equally.

$$
\begin{aligned}
H C I= & ((1 / 3) * \text { Literacy }+(4 / 9) * \text { Gross Enrolment } \\
& +(1 / 9) * \text { Rural mean year of schooling }+(1 / 9) * \text { Urban mean year of schooling })_{z-\text { score }}
\end{aligned}
$$

Online Service Availability and Performance Index. The OAPI evaluates the use of information and communication technology by government to deliver public services online. A predefined framework was used for evaluating and carrying out Web analysis. Four different aspects were used for the evaluation: User Friendliness, Security, Design, and Functionality. Each aspect was further evaluated using four parameters each. These aspects are in accord with UN evaluation criteria used in 2012 and 2014. In addition, these were found to be major criteria in World Wide Web consortium guidelines.

Functionality: Government Web sites must function properly, i.e., the Web links must be functional, and there must be a logical flow in links. Web links to external websites must be operational, which enhances information services and two-way communication between government and citizens. Furthermore, the technology must be uncomplicated and easy to comprehend.

Design: Government Web sites must have a proper color scheme. Photos and pictures must be used to enhance public participation. Furthermore, the coherency and structure of the Web site must be appropriate.

Security: Government Web sites are engaged in two-way communication with their citizens, including receiving and requesting inputs on government policies, programs, and regulations. To successfully complete the exchange of information, some form of electronic authentication of the citizen's identity is required. Therefore, a Web site must be able to handle citizen information and financial transactions where money is transferred on a secure network. It must be ensured that links do not lead to unauthorized sites.

User friendliness: Government has changed how it communicates with its citizens. To enhance interaction, language translations, a screen reader, and various accessibility options must be available.

Web analysis was performed for the Web pages of each e-governance service in every region in line with the UN EGDI. Each subcomponent of the performance indicator's functionality, design, security, and user friendliness was scored as described below:

$$
\text { Score }=0 \text { if not at all present; } 0.5 \text { if partially present; } 1 \text { if fully present. }
$$

The performance indicators are:

$$
\begin{gathered}
\text { Functionality index }=\text { sum (working of links, logical flow of links, external } \\
\text { links, use of uncomplicated technology) } \\
\text { Design index }=\text { sum (coherency, structure, colour scheme, pictures) } \\
\text { Security index = sum (authorization of users, transaction on security, data security, } \\
\text { links do not lead to unauthorized sites) } \\
\text { User friendliness }=\text { sum(language transactions, unambigious information, } \\
\text { screen reader access, accessibility options), }
\end{gathered}
$$

The OAPI score for each Web site was calculated according to Equation (6). The average of the OAPI scores for all the Web sites for a region was used to calculate the OAPI score for the region:

$$
O A P I=\operatorname{sum}(\text { functionality index, design index, security index, user friendliness) }
$$

Digital Government: Research and Practice, Vol. 1, No. 3, Article 20. Publication date: November 2020. 
E-governance-related Infrastructure Index. The performance indicators of EGII are the following:

- Number of Common Service Centers (CSCs): A CSC is an information and communication technology access point created by the government. It is also known as a rural kiosk or a tele-center. The number of such operational CSCs was taken into consideration.

- Number of E-services: The total number of e-governance services operating in a region.

- Presence of Data Centers in the Region: The availability of data centers is counted in a region in binary terms (0-Absent or 1-Present).

High accuracy of the e-governance-related infrastructure index was achieved by considering the number of CSCs and the number of e-services per 100 people. This was done as follows:

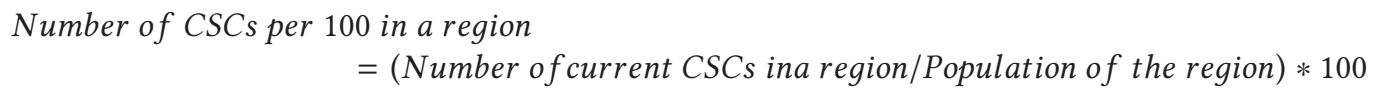

Number of e-services per 100 in a region

$$
=(\text { Number ofe }- \text { services in a region/Population of the region }) * 100
$$

Data Center in the Region $=0$ if unavailable; 1 if available

The average of all the states within the region was taken to be the value of a data center for a region. The overall EGII was formulated according to Equation (7):

$$
\begin{aligned}
E G I I= & ((2 / 5) * \text { No. of CSC's per } 100+(2 / 5) * \text { No. of E-Services per } 100 \\
& +(1 / 5) * \text { Data Centers in the Region })_{z-\text { score }}
\end{aligned}
$$

E-governance Performance Index. A region's EGPI reflects the electronic participation outcome from the services and infrastructure/facilities deployed by the government. The performance indicators are as follows:

- E-transactions per 100 people: the number of electronic transactions carried out by the region's population on a per-100 basis.

- E-transactions per E-service: the number of electronic transactions carried out by citizens per electronic service available in the region.

The overall EGPI is formulated as Equation (8):

EGPI $=((1 / 2) * \text { No. of E-Transacations per } 100+(1 / 2) * \text { No. of E-Transaction per E-Service })_{z-\text { score }}$

The overall Regional E-governance Development Index is then formulated according to Equation (9):

$$
\boldsymbol{R E G D I}=((1 / 5) * \boldsymbol{T I I}+(1 / 5) * \boldsymbol{H C I}+(1 / 5) \boldsymbol{O A P I}+(1 / 5) * \boldsymbol{E G I I}+(1 / 5) * \boldsymbol{E G P I}) .
$$

\subsection{Data Region}

The telecom circles (service areas) in India, as a developing nation, have been considered as the regions of interest for assessment index implementation. India is divided into 28 states and 7 Union territories, but generally telecommunication-related data are available for 19 telecom circles (out of 22 circles) according to the Telecom Regulatory Authority of India (www.trai.gov.in).

\section{ANALYSIS AND FINDINGS}

\subsection{Rankings 2014-16}

Table 4 shows the calculated REGDI values for 2014 and 2016 along with the ranking of the regions. A higher value of REGDI denotes that a region is high in the rankings (with a lower rank value) and vice versa. As seen 
Table 4. Rankings for the States of India Based on the Proposed Model

\begin{tabular}{lcccc}
\hline Indian States/ Regions & REGDI-2014 & Rank 2014 & REGDI-2016 & Rank 2016 \\
\hline Himachal Pradesh & 0.671319 & 1 & 0.627563 & 2 \\
Delhi & 0.631379 & 2 & 0.540959 & 3 \\
Kerala & 0.629882 & 3 & 0.660123 & 1 \\
Maharashtra & 0.568898 & 4 & 0.504281 & 6 \\
Tamil Nadu & 0.525322 & 5 & 0.531772 & 4 \\
Gujarat & 0.518738 & 6 & 0.516117 & 5 \\
Madhya Pradesh & 0.509884 & 7 & 0.403875 & 9 \\
Andhra Pradesh & 0.484010 & 8 & 0.495792 & 7 \\
North Eastern & 0.471094 & 9 & 0.399801 & 10 \\
Karnataka & 0.442949 & 10 & 0.375301 & 14 \\
Odisha & 0.435920 & 11 & 0.399337 & 11 \\
West Bengal & 0.410637 & 12 & 0.375840 & 13 \\
Rajasthan & 0.409601 & 13 & 0.214948 & 17 \\
Punjab & 0.400769 & 14 & 0.411237 & 8 \\
Assam & 0.365290 & 15 & 0.115137 & 19 \\
Uttar Pradesh & 0.354566 & 16 & 0.366358 & 15 \\
Jammu and Kashmir & 0.346604 & 17 & 0.309006 & 16 \\
Bihar & 0.302336 & 18 & 0.149739 & 18 \\
Haryana & 0.260572 & 19 & 0.379598 & 12 \\
\hline
\end{tabular}

for 2014, Himachal Pradesh, Delhi, Kerala, Maharashtra, and Tamil Nadu were the top five regions. However, for 2016, there was a slight change in the order, with Kerala, Himachal Pradesh, Delhi, Tamil Nadu, and Gujarat taking the top five positions.

Similarly, in 2014, the bottom five regions were Haryana, Bihar, Jammu \& Kashmir, Uttar Pradesh, and Assam, whereas in 2016, the bottom five were Assam, Bihar, Rajasthan, Jammu \& Kashmir, and Uttar Pradesh. The leading and lagging regions of India did not change drastically in two years. For all except a very few regions, the rankings were almost similar. This can be attributed to the rising population in the region, as a result of which e-governance-related activities also increased. Few regions obtained drastically improved coverage for e-governance that led to a significant change in rankings. A detailed ranking of regions based on different components of the REGDI is shown at the end of the article.

\subsection{Model Performance}

6.2.1 Validity of the Model. Based on criterion validity, the suggested framework appears to be suitable for assessing the development of e-governance services in the various states and regions of a developing nation like India. EGDI is already a well-established measurement index developed by the UN, which is why this assessment index was developed along similar lines. The data collection and experimental results have been compared to the existing EGDI to conclude its appropriateness in developing national conditions. However, with respect to new component addition, correlations were checked, and results are reported in Table 5.

It is apparent that no statistically significant ( $95 \%$ confidence interval) correlations were found between the newly added components (such as EGPI and EGII) and the existing components (such as HCI, TII, and OAPI). This suggests that the components are independent in nature and do not influence or become influenced by any other component within the model. Therefore, the model can be assumed to be valid from the component addition point of view.

Digital Government: Research and Practice, Vol. 1, No. 3, Article 20. Publication date: November 2020. 
Table 5. Correlations between Various Components of REGDI

\begin{tabular}{lccccc}
\hline 2014 & EGPI & EGII & HCI & TII & OAPI \\
\hline EGPI & 1 & -0.260 & 0.003 & 0.174 & -0.243 \\
EGII & -0.260 & 1 & 0.072 & -0.113 & 0.355 \\
\hline 2016 & EGPI & EGII & HCI & TII & OAPI \\
\hline EGPI & 1 & 0.012 & 0.075 & 0.200 & 0.354 \\
EGII & 0.012 & 1 & 0.036 & -0.202 & 0.179 \\
\hline
\end{tabular}

Table 6. Statistical Properties of the Model

\begin{tabular}{lccccccccc}
\hline 2014 & $\mathrm{N}$ & Range & Min & Max & Mean & Std. Deviation & Variance & Skewness & Kurtosis \\
\hline REGDI & 19 & 0.41 & 0.26 & 0.67 & 0.4600 & 0.11367 & 0.013 & 0.232 & -0.570 \\
EGPI & 19 & 1 & 0 & 1 & 0.5215 & 0.25363 & 0.064 & -0.150 & -0.235 \\
OAPI & 19 & 1 & 0 & 1 & 0.6375 & 0.27142 & 0.074 & -0.917 & 0.413 \\
EGII & 19 & 1 & 0 & 1 & 0.5519 & 0.22687 & 0.051 & -0.169 & 1.312 \\
HCI & 19 & 1 & 0 & 1 & 0.3850 & 0.26848 & 0.072 & 0.670 & -0.120 \\
TII & 19 & 1 & 0 & 1 & 0.2040 & 0.22010 & 0.048 & 2.803 & 9.887 \\
\hline 2016 & $\mathrm{N}$ & Range & Min & Max & Mean & Std. Deviation & Variance & Skewness & Kurtosis \\
\hline REGDI & 19 & 0.55 & 0.12 & 0.67 & 0.41 & 0.144867 & 0.021 & -0.377 & 0.054 \\
EGPI & 19 & 1 & 0 & 1 & 0.49 & 0.279639 & 0.078 & 0.136 & -0.559 \\
OAPI & 19 & 1 & 0 & 1 & 0.58 & 0.282723 & 0.080 & -0.742 & -0.146 \\
EGII & 19 & 1 & 0 & 1 & 0.37 & 0.232317 & 0.054 & 0.814 & 2.034 \\
HCI & 19 & 1 & 0 & 1 & 0.40 & 0.259692 & 0.067 & 0.65 & -0.107 \\
TII & 19 & 1 & 0 & 1 & 0.20 & 0.219749 & 0.048 & 2.811 & 9.938 \\
\hline
\end{tabular}

Table 7. Classification of Indian Regions According to the E-Readiness Index (ERI) Report of 2008

\begin{tabular}{|c|c|c|c|c|c|c|}
\hline$\overline{\text { ERI }}$ & Level 1 & Level 2 & Level 3 & Level 4 & Level 5 & Level 6 \\
\hline 2008 & $\begin{array}{l}\text { Tamil Nadu, } \\
\text { Delhi, Andhra } \\
\text { Pradesh, } \\
\text { Maharashtra, } \\
\text { Karnataka, } \\
\text { Chandigarh }\end{array}$ & $\begin{array}{l}\text { Kerala, WB, } \\
\text { Punjab, } \\
\text { Haryana, } \\
\text { Gujarat }\end{array}$ & $\begin{array}{l}\text { HP, UP, Goa } \\
\text { Andaman, } \\
\text { Bihar, MP, } \\
\text { Odisha, } \\
\text { Assam }\end{array}$ & $\begin{array}{l}\text { Sikkim, } \\
\text { Uttarakhand } \\
\text { Jharkhand } \\
\text { Chhattisgarh } \\
\text { Rajasthan }\end{array}$ & $\begin{array}{l}\text { Tripura, } \\
\text { Nagaland, } \\
\text { Puducherry, } \\
\text { Meghalaya }\end{array}$ & $\begin{array}{l}\text { J\&K, } \\
\text { Daman-Diu, } \\
\text { Dadra, } \\
\text { Lakshadweep } \\
\text { Mizoram, } \\
\text { Arunachal, } \\
\text { Manipur }\end{array}$ \\
\hline
\end{tabular}

In addition, the statistical properties of the model were checked with respect to the overall REGDI index and its individual components. Table 6 shows the results. It was found that data normality held well, with no major signs of skewness or kurtosis. Moreover, the low variance suggests that results were statistically reliable for both 2014 and 2016. Data normality was taken care of by data transformations, standardization, and normalization during the model formulation stage, and therefore statistical properties were under control for the various values.

6.2.2 Comparison of the Model with Other Regional Indices. Within the Indian context, the last major report on e-governance, which was focused on the e-readiness of the various regions of the country, was released in 2008. Table 7 shows the various levels. It was found that regions such as Tamil Nadu, Delhi, Andhra Pradesh, Maharashtra, and Karnataka were the most e-ready to adopt and implement e-governance services and related 
Table 8. Classification of Indian Regions According to the New Regional Index (REGDI) for 2014 and 2016

\begin{tabular}{llllll}
\hline Region & Level 1 & Level 2 & Level 3 & Level 4 & Level 5 \\
\hline 2014 & Himachal & Tamil Nadu & N.E. & Rajasthan & Jammu and \\
& Pradesh & Gujarat & Karnataka & Punjab & Kashmir \\
& Delhi & Madhya Pradesh & Odisha & Assam & Bihar \\
& Kerala & Andhra Pradesh & West Bengal & Uttar Pradesh & Haryana \\
& Maharashtra & & & & \\
\hline 2016 & Kerala & Gujarat & Madhya Pradesh & West Bengal & Rajasthan \\
& Himachal & Maharashtra & N.E. & Karnataka & Bihar \\
& Pradesh & Andhra Pradesh & Odisha & Uttar Pradesh & Assam \\
& Delhi & Punjab & Haryana & Jammu and & \\
& Tamil Nadu & & & Kashmir & \\
\hline
\end{tabular}

Table 9. Correlation of REGDI with Other Existing Regional Indices in India

\begin{tabular}{lccccccc}
\hline & $\begin{array}{c}\text { Human } \\
\text { Development } \\
\text { Index }\end{array}$ & $\begin{array}{c}\text { Health } \\
\text { Index }\end{array}$ & $\begin{array}{c}\text { GSDP Per } \\
\text { Capita }\end{array}$ & $\begin{array}{c}\text { NSDP Per } \\
\text { Capita }\end{array}$ & $\begin{array}{c}\text { Hunger } \\
\text { Index }\end{array}$ & $\begin{array}{c}\text { Under } \\
\text { Development } \\
\text { Index }\end{array}$ & $\begin{array}{c}\text { Aadhar } \\
\text { Enrollment }\end{array}$ \\
\hline 2014 & $0.583^{*}$ & $0.515^{*}$ & $0.521^{*}$ & $0.606^{* *}$ & -0.239 & -0.450 & - \\
2016 & $0.773^{* *}$ & $0.686^{* *}$ & $0.631^{* *}$ & $0.647^{* *}$ & -0.319 & $-0.619^{* *}$ & $0.679^{* *}$ \\
\hline
\end{tabular}

${ }^{*}$ Significant at $0.05(95 \%)$ level **Significant at $0.01(99 \%)$ level.

infrastructure. As can be seen from Table 8, which shows the levels achieved by various regions according to REGDI in 2014 and 2016, some of the most e-ready regions have been able to become the best-developed regions with respect to e-governance. This validates the rankings produced by the REGDI model and suggests that the results are not totally random with respect to the planning and implementation stage from 2008 to 2016-17.

Similarly, it was determined that the regions that are doing well in e-governance are also doing well on other measures, such as economic parameters and other regional indices. Table 9 shows the correlation between REGDI values in 2014 and 2016 with regional indices such as the Human Development Index, Health Index, Hunger Index, Under-Development Index, and econometric parameters such as GSDP per capita and NSDP per capita. Aadhar enrollments were also considered for different regions in 2015-16.

Significant correlations were found with economic indicators and other prominent index values, which validates the model findings. Regions that are doing well on the EGDI are also doing well on other aspects; this means that the findings are not spurious. Moreover, with negative indices like the Hunger Index, the REGDI correlation was found to be negative. It can be assumed from the results that all the e-governance-related components are positively impacted by other development parameters in the region.

\section{DISCUSSION}

\subsection{Comparison of Results}

The new REGDI model is superior to existing models like UN-EGDI, because the new components added to the model contribute in a substantial way. Comparative analyses for 2014 and 2016 are shown in Tables 10 and 11, respectively.

In 2014, REGDI improved significantly for regions such as Gujarat, Madhya Pradesh, Andhra Pradesh, and the North Eastern region compared to their UN-EGDI rankings. Even though they showed good performance with respect to e-governance for Gujarat $(E G P I=1)$, Madhya Pradesh $(E G P I=0.870334)$, and Andhra Pradesh 
Table 10. Comparative Analysis of REGDI 2014 and UN-EGDI 2014 Rankings

\begin{tabular}{lcccccc}
\hline Regions & REGDI-2014 & Rank 2014 & UN EGDI-2014 & UN Rank 2014 & EGPI & EGII \\
\hline Himachal Pradesh & 0.671319 & 1 & 0.687842 & 2 & 0.342936 & 0.950134 \\
Delhi & 0.631379 & 2 & 0.722102 & 1 & 0.636507 & 0.354083 \\
Kerala & 0.629882 & 3 & 0.686667 & 3 & 0.505177 & 0.584229 \\
Maharashtra & 0.568898 & 4 & 0.525187 & 4 & 0.676395 & 0.592537 \\
Tamil Nadu & 0.525322 & 5 & 0.491605 & 5 & 0.723999 & 0.427795 \\
Gujarat & 0.518738 & 6 & 0.303706 & 15 & 1.000000 & 0.682574 \\
Madhya Pradesh & 0.509884 & 7 & 0.358527 & 10 & 0.870334 & 0.603504 \\
Andhra Pradesh & 0.484010 & 8 & 0.311368 & 14 & 0.744948 & 0.740998 \\
North East & 0.471094 & 9 & 0.327381 & 12 & 0.373326 & 1.000000 \\
Karnataka & 0.442949 & 10 & 0.442210 & 6 & 0.574675 & 0.313444 \\
Odisha & 0.435920 & 11 & 0.400037 & 8 & 0.427160 & 0.552330 \\
West Bengal & 0.410637 & 12 & 0.433057 & 7 & 0.340536 & 0.413478 \\
Rajasthan & 0.409601 & 13 & 0.315233 & 13 & 0.566773 & 0.535534 \\
Punjab & 0.400769 & 14 & 0.389130 & 9 & 0.190053 & 0.646400 \\
Assam & 0.365290 & 15 & 0.295359 & 17 & 0.395755 & 0.544616 \\
Uttar Pradesh & 0.354566 & 16 & 0.265716 & 18 & 0.575028 & 0.400653 \\
Jammu \& Kashmir & 0.346604 & 17 & 0.339353 & 11 & 0.000000 & 0.714962 \\
Bihar & 0.302336 & 18 & 0.298497 & 16 & 0.186705 & 0.429483 \\
Haryana & 0.260572 & 19 & 0.174905 & 19 & 0.778143 & 0.000000 \\
\hline
\end{tabular}

Table 11. Comparative Analysis of REGDI 2016 and UN-EGDI 2016 Rankings

\begin{tabular}{lcccccc}
\hline Regions & REGDI-2016 & Rank 2016 & UN EGDI-2016 & UN Rank 2016 & EGPI & EGII \\
\hline Kerala & 0.660123 & 1 & 0.682012 & 2 & 0.956479 & 0.298101 \\
Himachal Pradesh & 0.627563 & 2 & 0.537471 & 4 & 0.525404 & 1.000000 \\
Delhi & 0.540959 & 3 & 0.723628 & 1 & 0.533911 & 0.000000 \\
Tamil Nadu & 0.531772 & 4 & 0.513730 & 5 & 0.699382 & 0.418287 \\
Gujarat & 0.516117 & 5 & 0.387990 & 12 & 0.837419 & 0.579196 \\
Maharashtra & 0.504281 & 6 & 0.553330 & 3 & 0.404988 & 0.456424 \\
Andhra Pradesh & 0.495792 & 7 & 0.365265 & 14 & 1.000000 & 0.383165 \\
Punjab & 0.411237 & 8 & 0.476903 & 6 & 0.175263 & 0.450210 \\
Madhya Pradesh & 0.403875 & 9 & 0.266463 & 16 & 0.726048 & 0.493936 \\
N.E. & 0.399801 & 10 & 0.391507 & 11 & 0.128673 & 0.695811 \\
Odisha & 0.399337 & 11 & 0.397351 & 9 & 0.390978 & 0.413655 \\
Haryana & 0.379598 & 12 & 0.384088 & 13 & 0.470514 & 0.275213 \\
West Bengal & 0.375840 & 13 & 0.422992 & 8 & 0.447698 & 0.162526 \\
Karnataka & 0.375301 & 14 & 0.450066 & 7 & 0.523787 & 0.002522 \\
Uttar Pradesh & 0.366358 & 15 & 0.291395 & 15 & 0.664352 & 0.293254 \\
Jammu \& Kashmir & 0.309006 & 16 & 0.395956 & 10 & 0.000000 & 0.357162 \\
Rajasthan & 0.214948 & 17 & 0.082640 & 18 & 0.459022 & 0.367798 \\
Bihar & 0.149739 & 18 & 0.133152 & 17 & 0.206307 & 0.142935 \\
Assam & 0.115137 & 19 & 0.035229 & 19 & 0.166702 & 0.303298 \\
\hline
\end{tabular}


$(E G P I=0.744948)$, these regions were ranked very low on UN-EGDI. Even the e-governance-related infrastructure was found to be very good for these regions, which was not considered in the UN-EGDI evaluations. Similarly, regions such as Jammu \& Kashmir and Punjab were found to be low on e-governance-related performance and infrastructure, but they were found to be high on the UN-EGDI rankings, which gives a wrong impression to the evaluators considering a ranking based on UN-EGDI.

Like the results of 2014, even in 2016 it was found that regions such as Himachal Pradesh, Gujarat, Andhra Pradesh, and Madhya Pradesh were good with respect to e-governance-related performance and infrastructure, but they were ranked low on UN-EGDI. However, regions such as Karnataka and Jammu \& Kashmir received high scores on UN-EGDI, but their performance and infrastructure conditions were not found to be good. Overall, it can be seen that almost $30 \%$ of the regions are improving on their rankings based on actual development.

The comparison signifies that the proposed REGDI model takes care of relevant components like performance and specific infrastructure within the region for citizens to access e-services. The proposed model can overcome the anomalies (of incorrect rankings of regions not performing well on e-governance) and gives more accurate results than the UN-EGDI model.

\subsection{Why the Results Are Better}

The better results from the proposed REGDI model can be attributed to the inclusion of more relevant components in the evaluation. Earlier, the only parameters considered in UN-EGDI were static parameters such as human capital, telecommunication infrastructure, and online availability, which can be good in regions that are well prepared for e-governance. However, the actual implementation of e-governance and the outcome in that region on this front denote the actual development of the region. E-governance-related performance and infrastructure might not be required in developed nations, but they are important issues in developing nations where large rural populations still exist. Therefore, concepts like Common Service Centers (Rural Kiosks/ Tele-centers) become very important for service delivery between government and citizens. Moreover, from a mathematical standpoint, the dependence on three parameters is increased to five parameters, which gives a more robust model at regional level.

\subsection{Research Contribution \& Novelty of Research}

From a research contribution point of view, the current article innovates in the following aspects:

- Formulation of a Regional E-governance Development Index for a developing nation like India, which did not exist earlier. The nature of developed and developing nations differs for e-governance, along with the difference between country-level and regional-level assessment. Hence, there is a need for a separate index to be formulated for development assessment at regional level for a developing nation. This article has provided that index.

- Implementation of the proposed index has been carried out on data for Indian regions for two years, 2014 and 2016, and the results have been compared with those from the existing UN-EGDI model and other regional indices.

- Inclusion of a greater number of parameters in the development assessment index to overcome the shortcomings of overdependence on three variables and non-inclusion of any outcome-based component.

- A quantifiable measure for e-governance in developing economies like India has been formulated in addition to the E-readiness Index, which is required in the current scenario, because much development is taking place with respect to e-governance.

\subsection{Implications of the Model}

There are several implications of the framework proposed here that could help the research community as well as key stakeholders move forward in the direction of better e-governance. Not only in India, but in every developing

Digital Government: Research and Practice, Vol. 1, No. 3, Article 20. Publication date: November 2020. 
country where a regional and federal structure exists, this study could be useful for evaluating the development of e-governance. Some of the specific implications of the study are described below.

Inclusive Growth Plan Formulation: The proposed index can be used to prepare an inclusive growth plan for the whole of the country based on regional development. The inclusive growth plan refers to the same preference for every region for e-governance development. The resource requirements may vary from region to region, but the preference and motivation to develop each region as compared to others will make the country's overall situation progressive. This proposed index will therefore help in assessing the development level of e-governance at regional level, finding out common and region-specific issues, rectifying them, and preparing an overall growth plan. In this way, the development of the whole country with respect to e-governance could be impacted.

Resource Inequality Measurement: Through the index, the resource distribution required for development of E-governance can be well evaluated across various regions. Some regions might be well provided with resources, whereas others might not be. An optimized resource allocation can be planned within several regions, and thus development of e-governance can be put on track.

Guidance to Foreign Investors: The framework will be helpful to foreign investors looking forward to investing in the host country under study. Knowledge of the development and readiness of the regions or states of the country will help them understand the growth scenario and ease of business dealing with respect to government. The investor will need to deal intensively with government departments while investing in any business opportunity, and with e-governance being developed in a region, that region will have more transparency and will become a favorable choice for the investor. In this way, government can showcase the development of a region on the country's map in front of various investors using this index.

Analyzing Governance Status: Through the proposed assessment model, the country's top-level administration can investigate the governance status of every region. The transparency and acceptability of government services to citizens and businesses can be analyzed. Based on development of the electronic mode for services, governments can take other initiatives. Moreover, better governance can lead to better economic development in the region. This study can indirectly be associated with assessment of economic growth and regional planning.

Technology and Acceptance: Government can also assess technological growth and advancement in various regions and states of the country. Through the technology, its acceptance in the form of service usage and its benefits can also be judged. This will help in maintaining the equilibrium of service provision and its usability by and accessibility to users in every region. The better the equilibrium and technology distribution, the better the governance will be.

\section{CONCLUSION}

To conclude, the model proposed in this article will be helpful as an evaluation tool for developing nations such as India and other countries to assess the development of e-governance in their respective countries. The quantitative assessment will not only give an indication of development, but will also be helpful in comparing growth in different regions, states, union territories, and even countries. The work is an extension of the UN assessment framework, but at the regional level.

India, being the second-most-populous country and the largest democracy in the world, needs to make a delivery plan for the various services in the country so its potential as the world's largest consumer market can be unleashed. This study is a step towards the current assessment of service delivery and how well the country is prepared to take on delivery challenges. Recently, India was rated to be the second-best country on the trust index; however, to maintain that trust, it is important for the government to deliver its services as promised to citizens and businesses. Unless government services improve, it will be difficult for the country to grow. Moreover, a specific plan needs to be prepared for service delivery according to the strengths and weaknesses of every state and region. This will enhance the inclusive growth plan irrespective of any favoritism. In addition, if any developing nation needs to improve on its rankings on the UN EGDI, which is evaluated every

Digital Government: Research and Practice, Vol. 1, No. 3, Article 20. Publication date: November 2020. 
two years, it must take an inclusive growth plan into account. Weak regions need to be identified and given immediate attention. Strong regions need to maintain their service delivery and provide mentorship to the weak ones in their development. Once all the regions are progressing and similar service delivery is being realized, the overall growth of the country on the e-governance development front will be automatically achieved. Once a country grows in e-governance, it becomes competent at the international level, comparably to developed nations, thereby increasing its economic development and obtaining more cash reserves.

Based on the current study and its implications, specific recommendations can be drawn up for India and other developing nations that are looking forward to evaluating the development of e-governance in every region. Specific recommendations for various groups based on their expectations [86] are discussed below.

The model can also be applied to other developing nations. For example, data points for various provinces of South Africa were searched, and it was found that except for e-transaction data, all other data points were publicly available. The various provinces of South Africa, which can be considered as regions for e-governance development assessment, can be measured on REGDI, and rankings can be derived for them. This will help in comparing inter-regional e-governance development and will also help a developing nation like South Africa to work on its weak regions, thereby helping the overall country to progress on the worldwide e-governance rankings.

From the research point of view, many new horizons can be explored through this study. First, the granularity of this study can be broken down further by extending every state's development measurement through this study to city and district level with respect to e-governance in every state. Finer granularity will lead to better identification of the problems in every region, meaning that state funds can be used more efficiently to develop e-governance. Second, the same study can be emulated in a different country to assess its development. Third, a comparative analysis can be done for different nations on different levels using the UN's e-governance development measureso better policies and infrastructural practices can be adopted. Fourth, qualitative aspects of development can also be brought into the study framework alongside quantitative practices. Finally, updated data can be collected every year to measure and compare the growth and development of e-governance in various regions of countries annually. This will help in measuring the effectiveness of the policies being implemented on a regular basis in each specific region.

\section{APPENDIX \\ Value of Components of REGDI \\ 2014}

\begin{tabular}{|l|c|c|c|c|c|c|c|}
\hline Telecom Circle & REGDI & Rank & EGPI & OAPI & EGII & HCI & TII \\
\hline Himachal Pradesh & 0.671319 & 1 & 0.342936 & 1.000000 & 0.950134 & 0.778984 & 0.284543 \\
\hline Delhi & 0.631379 & 2 & 0.636507 & 0.166305 & 0.354083 & 1.000000 & 1.000000 \\
\hline Kerala & 0.629882 & 3 & 0.505177 & 0.978087 & 0.584229 & 0.723717 & 0.358198 \\
\hline Maharashtra & 0.568898 & 4 & 0.676395 & 0.689941 & 0.592537 & 0.621754 & 0.263864 \\
\hline Tamil Nadu & 0.525322 & 5 & 0.723999 & 0.727052 & 0.427795 & 0.442819 & 0.304944 \\
\hline Gujarat & 0.518738 & 6 & 1.000000 & 0.451476 & 0.682574 & 0.245319 & 0.214322 \\
\hline Madhya Pradesh & 0.509884 & 7 & 0.870334 & 0.765506 & 0.603504 & 0.258811 & 0.051265 \\
\hline Andhra Pradesh & 0.484010 & 8 & 0.744948 & 0.646468 & 0.740998 & 0.127712 & 0.159924 \\
\hline North East & 0.471094 & 9 & 0.373326 & 0.381093 & 1.000000 & 0.488913 & 0.112136 \\
\hline Karnataka & 0.442949 & 10 & 0.574675 & 0.705060 & 0.313444 & 0.381471 & 0.240098 \\
\hline Odisha & 0.435920 & 11 & 0.427160 & 0.940460 & 0.552330 & 0.199365 & 0.060284 \\
\hline West Bengal & 0.410637 & 12 & 0.340536 & 0.712136 & 0.413478 & 0.485187 & 0.101848 \\
\hline Rajasthan & 0.409601 & 13 & 0.566773 & 0.724000 & 0.535534 & 0.105104 & 0.116595 \\
\hline
\end{tabular}

Digital Government: Research and Practice, Vol. 1, No. 3, Article 20. Publication date: November 2020. 
Continued.

\begin{tabular}{|l|c|c|c|c|c|c|c|}
\hline Telecom Circle & REGDI & Rank & EGPI & OAPI & EGII & HCI & TII \\
\hline Punjab & 0.400769 & 14 & 0.190053 & 0.283377 & 0.646400 & 0.595295 & 0.288717 \\
\hline Assam & 0.365290 & 15 & 0.395755 & 0.859400 & 0.544616 & 0.000000 & 0.026678 \\
\hline Uttar Pradesh & 0.354566 & 16 & 0.575028 & 0.576328 & 0.400653 & 0.185837 & 0.034982 \\
\hline Jammu \& Kashmir & 0.346604 & 17 & 0.000000 & 0.688415 & 0.714962 & 0.216151 & 0.113493 \\
\hline Bihar & 0.302336 & 18 & 0.186705 & 0.817052 & 0.429483 & 0.078439 & 0.000000 \\
\hline Haryana & 0.260572 & 19 & 0.778143 & 0.000000 & 0.000000 & 0.380083 & 0.144632 \\
\hline
\end{tabular}

2016

\begin{tabular}{|l|c|c|c|c|c|c|c|}
\hline Telecom Circle & REGDI & Rank & EGPI & OAPI & EGII & HCI & TII \\
\hline Kerala & 0.660123 & 1 & 0.956479 & 1.000000 & 0.298101 & 0.710969 & 0.335068 \\
\hline Himachal Pradesh & 0.627563 & 2 & 0.525404 & 0.573944 & 1.000000 & 0.721884 & 0.316584 \\
\hline Delhi & 0.540959 & 3 & 0.533911 & 0.170884 & 0.000000 & 1.000000 & 1.000000 \\
\hline Tamil Nadu & 0.531772 & 4 & 0.699382 & 0.825579 & 0.418287 & 0.414786 & 0.300824 \\
\hline Gujarat & 0.516117 & 5 & 0.837419 & 0.702938 & 0.579196 & 0.251040 & 0.209993 \\
\hline Maharashtra & 0.504281 & 6 & 0.404988 & 0.768415 & 0.456424 & 0.636036 & 0.255540 \\
\hline Andhra Pradesh & 0.495792 & 7 & 1.000000 & 0.781856 & 0.383165 & 0.160703 & 0.153236 \\
\hline Punjab & 0.411237 & 8 & 0.175263 & 0.478346 & 0.450210 & 0.664005 & 0.288360 \\
\hline Madhya Pradesh & 0.403875 & 9 & 0.726048 & 0.530697 & 0.493936 & 0.222160 & 0.046532 \\
\hline North East & 0.399801 & 10 & 0.128673 & 0.557042 & 0.695811 & 0.478556 & 0.138923 \\
\hline Odisha & 0.399337 & 11 & 0.390978 & 0.925486 & 0.413655 & 0.196591 & 0.069975 \\
\hline Haryana & 0.379598 & 12 & 0.470514 & 0.571568 & 0.275213 & 0.455003 & 0.125693 \\
\hline West Bengal & 0.375840 & 13 & 0.447698 & 0.643186 & 0.162526 & 0.503564 & 0.122228 \\
\hline Karnataka & 0.375301 & 14 & 0.523787 & 0.704319 & 0.002522 & 0.390482 & 0.255397 \\
\hline Uttar Pradesh & 0.366358 & 15 & 0.664352 & 0.636902 & 0.293254 & 0.197985 & 0.039297 \\
\hline Jammu \& Kashmir & 0.309006 & 16 & 0.000000 & 0.862355 & 0.357162 & 0.251467 & 0.074047 \\
\hline Rajasthan & 0.214948 & 17 & 0.459022 & 0.000000 & 0.367798 & 0.132594 & 0.115325 \\
\hline Bihar & 0.149739 & 18 & 0.206307 & 0.247080 & 0.142935 & 0.152375 & 0.000000 \\
\hline Assam & 0.115137 & 19 & 0.166702 & 0.069136 & 0.303298 & 0.000000 & 0.036551 \\
\hline
\end{tabular}

Prominent data collection links for the Indian region are:

- http://www.trai.nic.in/

- http://www.censusindia.gov.in/

- https://data.gov.in/

- http://mhrd.gov.in/

- http://etaal.gov.in

- http://csc.gov.in/

- http://datacentres.nic.in/

- http://www.nic.in/.

\section{ACKNOWLEDGMENTS}

The authors wish to thank the team of the Open Government Data Portal of India for providing access to the various datasets for different regions of India. This article is an extension of a conference paper [87].

\footnotetext{
Digital Government: Research and Practice, Vol. 1, No. 3, Article 20. Publication date: November 2020.
} 


\section{REFERENCES}

[1] S. K. Sharma. 2015. Adoption of E-government services: The role of service quality dimensions and demographic variables. Transform. Gov.: People, Proc. Policy 9, 2 (2015), 207-222.

[2] T. V. Prasad. 2003. E-governance and standardization. In Proceedings of the Conference on Convergent Technologies for the Asia-Pacific Region (TENCON'03). IEEE, 198-202.

[3] United Nations Report. 2012. UN E-Governance Survey Report 2012. Retrieved from http://unpan3.un.org/egovkb/Portals/egovkb/ Documents/un/2012-Survey/unpan048065.pdf.

[4] A. A. A. R. Al Athmay. 2013. E-governance in Arab countries: Status and challenges. Glob. 7. Bus. Res. 7, 5 (2013), 79-98.

[5] X. Papadomichelaki, B. Magoutas, C. Halaris, D. Apostolou, and G. Mentzas. 2006. A review of quality dimensions in E-government services. In Electronic Government. Springer, Berlin, 128-138.

[6] World Bank. 2005. World Bank: Linking administrative reform to economic growth patterns: Review of methods and findings. Retreived from http://documents.banquemondiale.org/curated/fr/170021468332976401/361430ENGLISH01nd1tracking01PUBLIC1.doc.

[7] Price Waterhouse Coopers. 2007. The road ahead for public service delivery. Retrieved from http://www.pwc.com/en_GX/gx/psrc/pdf/ the_road_ahead_for_public_service_delivery.pdf.

[8] Department of Economic and Social Affairs, UN. 2014. UN E-Government Survey 2014-E-Government for the Future We Want. Retrieved from http://unpan3.un.org/egovkb/Portals/egovkb/Documents/un/2014-Survey/E-Gov_Complete_Survey-2014.pdf.

[9] The Economist Intelligence Unit 2009. E-Readiness rankings 2009-The usage imperative. Retrieved from http://graphics.eiu.com/pdf/ E-readiness\%20rankings.pdf.

[10] European Union. 2009. Smarter, faster, better E-government-Report for the European Commission. Retrieved from https://joinup.ec.europa.eu/sites/default/files/files_epractice/sites/Smarter\%2C\%20Faster\%2C\%20Better\%20eGovernment\%20$\% 208$ th\%20Benchmark\%20Measurement.pdf.

[11] GOI. 2008. INDIA: E-readiness assessment report 2008-for states/union territories. Retrieved from http://www.doitc.rajasthan.gov.in/ administrator/Lists/Downloads/Attachments/19/e-Readiness_20Report_202008.pdf.

[12] N. S. Kalsi, R. Kiran, and S. C. Vaidya. 2009. Effective E-governance for good governance in India. Int. Rev. Bus. Res. Pap. 5, 1 (2009), 212-229.

[13] S. Goel, R. Dwivedi, and A. M. Sherry. 2012. Critical factors for successful implementation of E-governance programs: A case study of HUDA. Glob. 7. Flex. Syst. Manag. 13, 4 (2012), 233-244.

[14] F. Diniz, V. K. Upadhyay, F. Dinizis, and V. K. Upadhyayis. 2014. A social and economic development index-a state level approach for India. Rom. 7. Reg. Sci. 8, 2 (2014), 62-80.

[15] R. De. 2006. Evaluation of E-government systems: Project assessment vs. development assessment. In Proceedings of the Springer 5th International Conference on Electronic Government (EGOV'06). 317-328.

[16] S. Madon. 2004. Evaluating the developmental impact of e-governance initiatives: An exploratory framework. The Electronic fournal of Information Systems in Developing Countries 20, 1 (2004), 1-13. Retreived from https://onlinelibrary.wiley.com/doi/pdf/10.1002/j.16814835.2004.tb00132.x.

[17] H. R. Schaffer. 1996. Social Development. Blackwell Publishing.

[18] K. Munshi. 2004. Social learning in a heterogeneous population: Technology diffusion in the Indian green revolution. F. Dev. Econ. 73, 1 (2004), 185-213.

[19] A. Agrawal, P. Shah, and V. Wadhwa. 2008. EGOSQ-Users' assessment of E-governance online-services: A quality measurement instrumentation. In Foundations of E-government, M. A. Hirwade (Ed.). GIFT Publications.

[20] I. A. Alghamdi, R. Goodwin, and G. Rampersad. 2011. E-government readiness assessment for government organizations in developing countries. Comput. Inf. Sci. 4, 3 (2011), 3.

[21] R. Arendsen, T. M. van Engers, and W. Schurink. 2008. Adoption of high impact governmental e-services: Seduce or enforce? In Electronic Government. Springer Berlin, 73-84.

[22] K. Axelsson and U. Melin. 2008. Citizen participation and involvement in e-government projects: An emergent framework. In Electronic Government. Springer Berlin, 207-218.

[23] N. A. Azab, S. Kamel, and G. Dafoulas. 2009. A suggested framework for assessing electronic government readiness in Egypt. Electron f. e-Govern. 7, 1 (2009), 11-28.

[24] A. Balog, G. Bàdulescu, R. Bàdulescu and F. Petrescu. 2008. E-ServEval: A system for quality evaluation of the on-line public services. Rev. Inf. Econ. 2, 46 (2008) 18-21.

[25] J. Becker, B. Niehaves, P. Bergener, and M. Räckers. 2008. Digital divide in e-government: The e-inclusion gap model. In Electronic Government. Springer Berlin, 231-242.

[26] D. Bhatia, S. C. Bhatnagar, and J. Tominaga. 2009. How do manual and e-government services compare? Experiences from India. Information and Communications for Development 2009: Extending Reach and Increasing Impact, 67-82. Retreived from http: //documents1.worldbank.org/curated/en/645821468337815208/pdf/487910PUB0EPI1101Official0Use0Only1.pdf.

[27] S. C. Bhatnagar and N. Singh. 2010. Assessing the impact of e-government: A study of projects in India. Inf. Technol. Inter. Dev. 6, 2 (2010), 109-127.

Digital Government: Research and Practice, Vol. 1, No. 3, Article 20. Publication date: November 2020. 
[28] T. X. Bui, S. Sankaran, and I. M. Sebastian. 2003. A framework for measuring national e-readiness. Int. f. Electron. Bus. 1, 1 (2003), 3-22.

[29] S. E. Colesca and L. Dobrica. 2008. Adoption and use of e-government services: The case of Romania. F. Appl. Res. Technol. 6, 3 (2008), 204-217.

[30] M. J. D'agostino, R. Schwester, T. Carrizales, and J. Melitski. 2011. A study of e-government and e-governance: An empirical examination of municipal websites. Pub. Adm. Quart. 35, 1 (2011), 3-25.

[31] S. S. Dawes, T. A. Pardo, and A. M. Cresswell. 2003. Designing government information access programs: A holistic approach. In Proceedings of the 36th Annual Hawaii International Conference on System Sciences. IEEE, 9.

[32] J. Esteves and R. C. Joseph. 2008. A comprehensive framework for the assessment of e-government projects. Gov. Inf. Quart. 25, 1 (2008), $118-132$.

[33] E. Estevez and T. Janowski. 2013. Electronic governance for sustainable development-Conceptual framework and state of research. Gov. Inf. Quart. 30, (2013), S94-S109.

[34] C. Halaris, B. Magoutas, X. Papadomichelaki, and G. Mentzas. 2007. Classification and synthesis of quality approaches in e-government services. Internet Res. 17, 4 (2007), 378-401.

[35] B. A. Hamilton. 2012. Building a methodology for measuring the value of E-services. USA Social Security Administration. Retreived from https://web.archive.org/web/20041015063953/http://smartcard.gov/information/measuring_finalreport.pdf.

[36] M. Iribarren, G. Concha, G. Valdes, M. Solar, M. T. Villarroel, P. Gutiérrez, and A. Vásquez. 2008. Capability maturity framework for e-government: A multi-dimensional model and assessing tool. In Electronic Government, Springer Berlin, 136-147.

[37] N. S. Kalsi and R. Kiran. 2013. E-governance success factors: An analysis of e-governance initiatives of ten major states of India. Int. F. Pub. Sect. Manag. 26, 4 (2013), 320-336.

[38] D. Kampitaki, E. Tambouris, and K. Tarabanis. 2008. E-electioneering: Current research trends. In Electronic Government, Springer Berlin, 184-194.

[39] M. Kunstelj and M. Vintar. 2004. Evaluating the progress of e-government development: A critical analysis. Inf. Polity 9, 3 (2004), $131-148$

[40] B. Magoutas and G. Mentzas. 2010. SALT: A semantic adaptive framework for monitoring citizen satisfaction from e-government services. Expert Syst. Appl. 37, 6 (2010), 4292-4300.

[41] N. Mnjama and J. Wamukoya. 2007. E-government and records management: An assessment tool for e-records readiness in government. Electron. Lib. 25, 3 (2007), 274-284.

[42] J. M. Montagna. 2005. A framework for the assessment and analysis of electronic government proposals. Electron. Commer. Res. Appl. 4,3 (2005), 204-219.

[43] I. H. Osman, A. Anouze, Z. Irani, H. Lee, A. Balc1, T. Medeni, and V. Weerakkody. 2011. A new COBRAS framework to evaluate EGovernment services: A citizen centric perspective. In Proceedings of the T-government Workshop. Retreived from https://www. researchgate.net/publication/228845385_A_new_cobras_framework_to_evaluate_e-government_services_a_citizen_centric_ perspective.

[44] D. Potnis and T. A. Pardo. 2011. Mapping the evolution of e-readiness assessments. Transform. Gov.: People, Proc. Policy 5, 4 (2011), 345-363.

[45] N. P. Rana, Y. K. Dwivedi, and M. D. Williams. 2013. Analysing challenges, barriers, and CSF of e-governance adoption. Transform. Gov: People, Proc. Policy 7, 2 (2013), 177-198.

[46] M. P. Sebastian and K. K. Supriya. 2013. E-governance readiness: Challenges for India. IIM Kozhikode Soc. Manag. Rev. 2, 1 (2013), 31-42.

[47] H. Singh, A. Das, and D. Joseph. 2004. Country-level determinants of e-government maturity. In Proceedings of the 1st e-Government SIG Pre-ICIS Workshop.

[48] G. Singh, R. D. Pathak, R. Naz, and R. Belwal. 2010. E-governance for improved public sector service delivery in India, Ethiopia, and Fiji. Int. f. Pub. Sect. Manag. 23, 3 (2012), 254-275.

[49] A. Tamara and A. Amer. 2010. A general framework for e-government: Definition maturity challenges, opportunities, and success. Eur. 7. Sci. Res. 39, 1 (2010), 29-42.

[50] R. Tripathi and M. P. Gupta. 2014. Evolution of government portals in India: Mapping over stage models. J. Enterp. Inf. Manag. 27, 4 (2014), 449-474.

[51] L. Van Velsen, T. Van der Geest, M. Terhedde, and W. Derks. 2008. Engineering user requirements for e-government services: A Dutch case study. In Electronic Government, Springer Berlin, 243-254.

[52] C. C. Yu. 2008. Building a value-centric e-government service framework based on a business model perspective. In Electronic Government, Springer Berlin, 160-171.

[53] W. Welch. 2000. The Information Society Index (ISI) 2000. Development Outreach. Retrieved from http://www.gsid.nagoya-u.ac.jp/ sotsubo/Information_Society_Index.pdf.

[54] J. Y. Jung, J. L. Qiu, and Y. C. Kim. 2001. Internet connectedness and inequality: Beyond the "divide." Commun. Res. 28,4 (2001), 507-535.

[55] M. Desai, S. Fukuda-Parr, C. Johansson, and F. Sagasti. 2002. Measuring the technology achievement of nations and the capacity to participate in the network age. F. Hum. Dev. 3, 1 (2002), 95-122.

[56] UN - DPEPA. 2002. Benchmarking E-government: A Global Perspective. Retrieved from https://publicadministration.un.org/egovkb/ Portals/egovkb/Documents/un/English.pdf.

Digital Government: Research and Practice, Vol. 1, No. 3, Article 20. Publication date: November 2020. 
[57] H. Selhofer and T. Hüsing. 2002. The Digital Divide Index-A Measure of Social Inequalities in the Adoption of ICT. In Proceedings of the 10th European Conference on Information Systems (ECIS'02). 1273-1286.

[58] T. Hüsing and H. Selhofer. 2004. DIDIX: A digital divide index for measuring inequality in IT diffusion. IT Soc. 17 (2004), 21-38.

[59] International Telecommunication Union. 2003. World telecommunication development report 2003. Retrieved from https://www.itu. int/net/wsis/tunis/newsroom/stats/WorldTelecomDevelopmentReport-2003_E.pdf.

[60] International Telecommunication Union. 2005. The digital opportunity index-a user's index., Retrieved from https://www.itu.int/ITUD/ict/doi/material/doi-guide.pdf.

[61] S. Dutta, B. Lanvin, and F. Paua (Eds.). 2004. The Global Information Technology Report 2003-2004: Towards an Equitable Information Society. Oxford University Press, UK.

[62] S. Dutta and I. Mia. 2010. The global information technology report 2009-2010. In Proceedings of the World Economic Forum and INSEAD, SRO.

[63] S. Baller, S. Dutta, and B. Lanvin. 2013. Global information technology report 2016, Geneva, Ouranos (2016) Bejarano, A., J. Angarita y C. Velandia, Implicaciones pedagógicas del uso de las TICs en la educación superior. Revista de Tecnología, 12(3), pp. 36-56. Retreived from https://www.researchgate.net/profile/German_Castro_Bernal/publication/307511712_The_Global_Information_ Technology_Report_2016/links/57c7077108ae28c01d4f7da2/The-Global-Information-Technology-Report-2016.pdf.

[64] O. B. I. Toshio. 2009. Waseda University International e-government rankings 2005-2009. In Global E-Governance: Advancing EGovernance Through Innovation and Leadership, Vol. 2. IOS Press, 163.

[65] T. Obi and N. Iwasaki. 2015. A Decade of World E-Government Rankings, Vol. 7, IOS Press.

[66] M. Hathaway. 2013. Cyber Readiness Index 1.0. Retrieved from https://www.belfercenter.org/sites/default/files/files/publication/cyberreadiness-index-1point0.pdf.

[67] United Nations. 2018. 2018 UN E-Government Survey. Retrieved from https://www.un.org/development/desa/publications/2018-un-egovernment-survey.html.

[68] A. Whitmore. 2012. A statistical analysis of the construction of the UN e-government development index. Gov. Inf. Quart. 291 (2012), 68-75.

[69] A. Ayanso, D. Chatterjee, and D. I. Cho. 2011. E-government readiness index: A methodology and analysis. Gov. Inf. Quart. 284 (2011), $522-532$.

[70] A. Rorissa, D. Demissie, and T. Pardo. 2011. Benchmarking e-government: A comparison of frameworks for computing e-government index and ranking. Gov. Inf. Quart. 283 (2011), 354-362.

[71] D. D. Potnis. 2010. Measuring e-governance as an innovation in the public sector. Gov. Inf. Quart. 271 (2010), 41-48.

[72] C. Ciborra and D. D. Navarra. 2005. Good governance, development theory, and aid policy: Risks and challenges of e-government in Jordan. Inf. Technol. Dev. 11, 2 (2005), 141-159.

[73] P. Søgaard. 2004. Co-ordination of e-government: Between politics and pragmatics. In Networked Information Technologies. Kluwer Academic Publishers, 53-77.

[74] R. Kemp, S. Parto, and R. B. Gibson. 2005. Governance for sustainable development: Moving from theory to practice. Int. 7. Sustain. Dev. 8, 1-2 (2005), 12-30.

[75] V. Homburg. 2004. E-government and NPM: A perfect marriage? In Proceedings of the 6th International Conference on Electronic Commerce. ACM, 547-555.

[76] V. A. Poulose. 2010. Essential stages of implementation and precautions. E-governance and infrastructure: Looking ahead. RITES 7. 1, $3(2010), 9-1$.

[77] C. P. Barthwal. 2003. E-governance for good governance. Indian 7. Polit. Sci. 285-308.

[78] TRAI. 2014. Press releases documents. Retrieved from http://www.trai.gov.in/WriteReadData/WhatsNew/Documents/ Press\%20Release\%20on\%20'Telecom\%20Subscription\%20Data\%20as\%20on\%2031st\%20January,\%202014'.pdf.

[79] R. Rose. 2005. A global diffusion model of e-governance. f. Pub. Policy 25, 1 (2005), 5-27.

[80] W. DeLone and E. McLean. 2003. The DeLone and McLean model of information systems success: A ten-year update. F. Manag. Inf. Syst. 19, 4 (2003), 9-30.

[81] S. Marche and J. D. McNiven. 2003. E-government and e-governance: The future isn't what it used to be. Can. F. Adm. Sci./Rev. Canad. Sci. l'Admin. 20, 1 (2003), 74-86.

[82] M. Shah. 2007. E-governance in India: Dream or reality? Int. f. Educ. Dev. Using ICT 3, 2 (2007), 125-137.

[83] J. S. Hiller and F. Bélanger. 2001. Privacy strategies for electronic government. E-government 200, (2001), 162-198.

[84] Z. Ebrahim and Z. Irani. 2005. E-government adoption: Architecture and barriers. Bus. Proc. Manag. F. 11, 5 (2005), $589-611$.

[85] J. W. Tukey. 1977. Exploratory Data Analysis. Reading 7, Addison-Wesley.

[86] J. Rowley. 2011. E-government stakeholders-Who are they and what do they want? Int. f. Inf. Manag. 31, 1 (2011), 53-62.

[87] R. Gupta, S. K. Muttoo and S. K. Pal. 2017. The need of a development assessment index for e-governance in India. In Proceedings of the 10th International Conference on Theory and Practice of Electronic Governance. ACM, 414-422.

Received February 2019; revised September 2019; accepted February 2020

Digital Government: Research and Practice, Vol. 1, No. 3, Article 20. Publication date: November 2020. 